\section{SANDIA REPORT}

SAND95-0070 • UC-600

Unlimited Release

Printed July 1995
RECEIVED

MAY 15 1996

OSTI

\title{
Adaptive Sampling Approach to Environmental Site Characterization: Phase I Demonstration
}

Robert J. Floran, Grace E. Bujewski, Robert L. Johnson

Prepared by

Sandia National Laboratories

Albuquerque, New Mexico 87185 and Livermore, California 94550

for the United States Department of Energy

under Contract DE-AC04-94AL85000

Approved for public release; distribution is unlimited. 
Issued by Sandia National Laboratories, operated for the United States Department of Energy by Sandia Corporation.

NOTICE: This report was prepared as an account of work sponsored by an agency of the United States Government. Neither the United States Government nor any agency thereof, nor any of their employees, nor any of their contractors, subcontractors, or their employees, makes any warranty, express or implied, or assumes any legal liability or responsibility for the accuracy, completeness, or usefulness of any information, apparatus, product, or process disclosed, or represents that its use would not infringe privately owned rights. Reference herein to any specific commercial product, process, or service by trade name, trademark, manufacturer, or otherwise, does not necessarily constitute or imply its endorsement, recommendation, or favoring by the United States Government, any agency thereof or any of their contractors or subcontractors. The views and opinions expressed herein do not necessarily state or reflect those of the United States Government, any agency thereof or any of their contractors.

Printed in the United States of America. This report has been reproduced directly from the best available copy.

Available to DOE and DOE contractors from Office of Scientific and Technical Information

PO Box 62

Oak Ridge, TN 37831

Prices available from (615) 576-8401, FTS 626-8401

Available to the public from

National Technical Information Service

US Department of Commerce

5285 Port Royal Rd

Springfield, VA 22161

NTIS price codes

Printed copy: A03

Microfiche copy: A01 
SAND95-0070

Distribution

Unlimited Release

Category UC-600

Printed July 1995

\title{
Adaptive Sampling Approach to Environmental Site Characterization: Phase I Demonstration
}

\author{
Robert J. Floran and Grace E. Bujewski \\ Sandia National Laboratories \\ Albuquerque, NM 87185-0719 \\ Robert L. Johnson \\ Argonne National Laboratory \\ Argonne, IL 60439
}

\begin{abstract}
A technology demonstration that optimizes sampling strategies and real-time data collection was carried out at the Kirtland Air Force Base (KAFB) RB-11 Radioactive Burial Site, Albuquerque, New Mexico in August 1994. The project, which was funded by the Strategic Environmental Research and Development Program (SERDP), involved the application of a geostatistical-based Adaptive Sampling methodology and software with on-site field screening of soils for radiation, organic compounds and metals. The software, known as Plume ${ }^{T M}$, was developed at Argonne National Laboratory as part of the DOE/OTD-funded Mixed Waste Landfill Integrated Demonstration (MWLID).

The objective of the investigation was to compare an innovative Adaptive Sampling approach that stressed real-time decision-making with a conventional RCRA-driven site characterization carried out by the Air Force. The latter investigation used a standard drilling and sampling plan as mandated by the Environmental Protection Agency (EPA). To make the comparison realistic, the same contractors and sampling equipment (Geoprobe $B$ soil samplers) were used. In both investigations, soil samples were collected at several depths at numerous locations adjacent to burial trenches that contain low-level radioactive waste and animal carcasses; some trenches may also contain mixed waste. Neither study revealed the presence of contaminants appreciably above risk based action levels, indicating that minimal to no migration has occurred away from the trenches. The combination of Adaptive Sampling with field screening achieved a similar level of confidence compared to the Resource Conservation and Recovery Act (RCRA) investigation regarding the potential migration of contaminants at the site. By comparison, the RCRA investigation regarding the potential migration of contaminants at the site. By comparison, the Adaptive Sampling program drilled 28 locations (vs. 36 for the conventional investigation), collected 81
\end{abstract}


samples (vs. 163), and sent 15 samples (vs. 163) off-site for laboratory analysis. In addition, the field work took $31 / 2$ days compared to 13 days for the RCRA investigation. These figures translate into large cost savings because $22 \%$ fewer boreholes were drilled, $50 \%$ fewer samples were collected, and $91 \%$ fewer samples were analyzed off-site. Of these costs, the most significant savings involved laboratory analyses which typically cost greater than $\$ 1 \mathrm{~K}$ per sample. Additional costs associated with the increased level of field screening carried out and costs associated with the use of the Adaptive Sampling software are relatively minor compared to the savings achieved.

During the field demonstration, a SunSPARC workstation containing the geostatistical program was successfully linked via the Internet with an identical workstation at Argonne. In the near future, it will be possible to support real-time sampling decisions in the field from remote locations thousands of miles away. 


\section{ACKNOWLEDGMENTS}

This work was funded by the Strategic Environmental Research and Development Program (SERDP) and the U.S. Army Corps of Engineers under the Military Interdepartmental Purchase Request Number E8794L054/SNL2, a joint DOD/DOE/EPA initiative to develop and demonstrate innovative methods for environmental site cleanup. We would also like to acknowledge the Mixed Waste Landfill Integrated Demonstration (MWLID) project, which is funded through DOE's Office of Technology Development (OTD). The MWLID demonstration at the KAFB RB-11 site in 1993 and previous funding of Plume ${ }^{\text {TM }}$ development at Argonne National Laboratory provided the technical foundation and inspiration for the work carried out under SERDP. We would like to thank the Environmental Management Division of Kirtland Air Force Base, New Mexico, under the direction of Col. Thomas A. Norris, for their cooperation and their support. 


\section{CONTENTS}

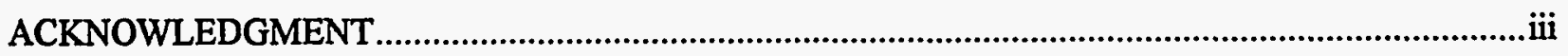

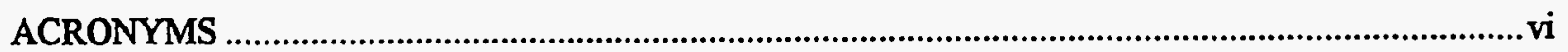

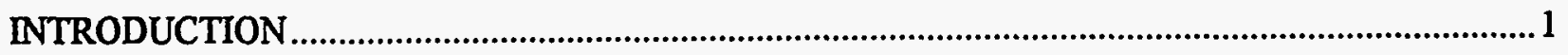

PREVIOUS STUDIES: KAFB RCRA INVESTIGATION............................................................

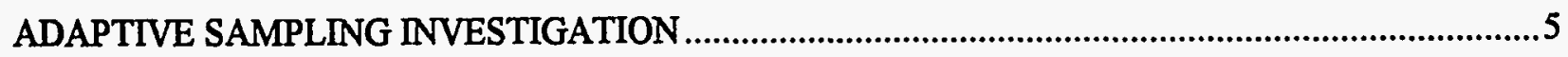

APPLICATION OF THE ADAPTIVE SAMPLING METHODOLOGY ........................................6

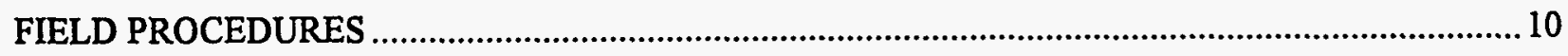

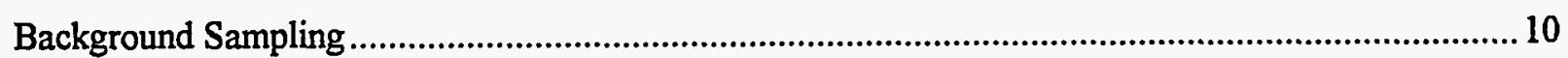

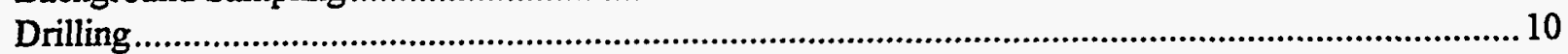

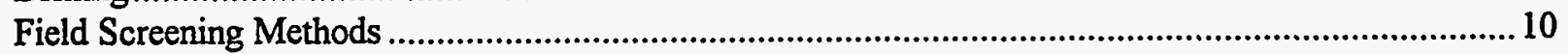

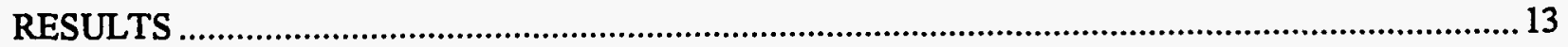

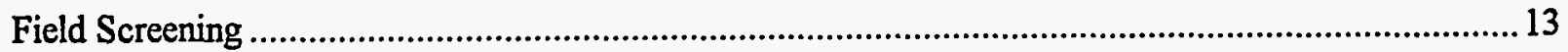

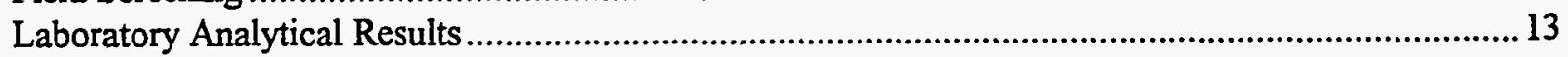

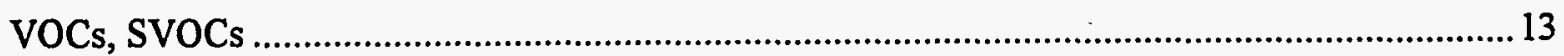

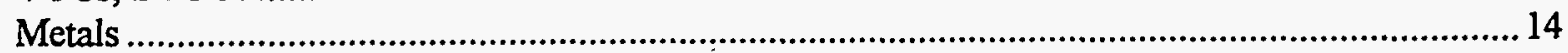

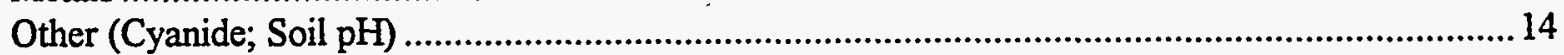

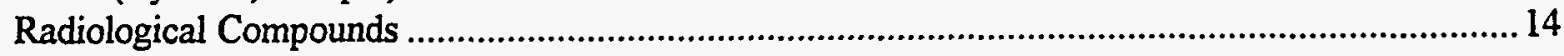

Data Transfer Using the Adaptive Sampling Methodology ...................................................... 14

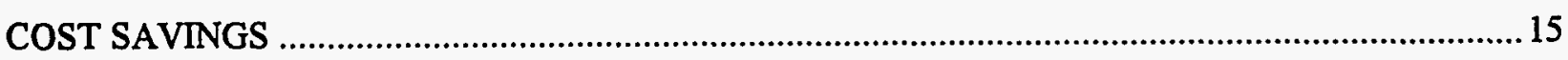

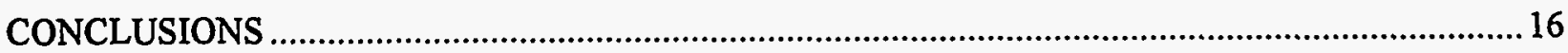

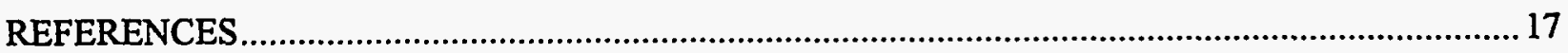

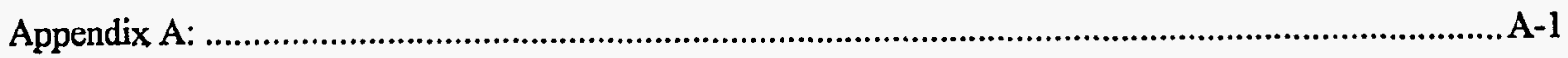




\section{Figures}

Figure 1. Location map of the RB-11 landfill, Kirtland Air Force Base, New Mexico.

Figure 2. RB-11 site showing infrastructure, inferred location of waste trenches and surrounding disturbed ground. Background sampling points are shown at perimeter (RB11-1 through RB11-4).

Figure 3. Plan view of RB-11 conceptual model with locations for Adaptive Sampling and RCRA soil bores.

Figure 4. North-south cross-section of RB-11 conceptual model............................................................8

Figure 5. Flow diagram illustrating how splits from each subsurface soil sample were allocated for onsite field screening and off-site laboratory analyses.

\section{Tables}

Table IA. Summary of Reportable Concentrations for Soil Analysis at RB-11 Site Kirtland AFB, New Mexico.

Table 1.1A. Summary of VOC and SVOC Background Samples at RB-11 Site Kirtland AFB, NM

Table 1.1B. Summary of Metals, Radioactive, and Other Background Soil Samples at RB-11 Site Kirtland AFB, NM.

Table 11.C. Summary of Field Screening Gamma-ray Spectroscopy for Background Soil Samples at RB-11 Site Kirtland AFB, NM.

Table 2A. Radiometric Analysis Results

Table 2.1A. Radiometric QAVQ Results, 27-Oct-94 and 9-Nov-94. 


\section{ACRONYMS}

$\begin{array}{ll}\text { DOE } & \text { Department of Energy } \\ \text { EPA } & \text { Environmental Protection Agency } \\ \text { ft } & \text { feet } \\ \text { FTP } & \text { file transfer protocol } \\ \text { G-M } & \text { Geiger-Muller } \\ \text { HHRB } & \text { human health risk based } \\ \text { KAFB } & \text { Kirtland Air Force Base } \\ \text { m } & \text { meter } \\ \text { MWLID } & \text { Mixed Waste Landfill Integrated Demonstration } \\ \text { OTD } & \text { Office of Technology Development } \\ \text { PID } & \text { photoionization detector } \\ \text { ppm } & \text { parts per million } \\ \text { QA } & \text { Quality Assurance } \\ \text { QC } & \text { Quality Control } \\ \text { RCRA } & \text { Resource Conservation and Recovery Act } \\ \text { RFI } & \text { RCRA Facility Investigation } \\ \text { SERDP } & \text { Strategic Environmental Research and Development Program } \\ \text { SNL } & \text { Sandia National Laboratories } \\ \text { SVOCs } & \text { semi-volatile organic compounds } \\ \text { TAL } & \text { Target Analyte List } \\ \text { VOCs } & \text { volatile organic compounds } \\ \text { XRF } & \text { years } \\ \text { yrs } & \end{array}$




\section{INTRODUCTION}

The Kirtland Air Force Base RB-11 radioactive waste site, located in Bernalillo County, southeast of Albuquerque (Figure 1), is a $0.02 \mathrm{sq} . \mathrm{km}$. (4.5 acre) landfill containing nine or ten disposal trenches (the exact number is unknown). Incomplete records suggest that the four earliest trenches located at the southern end of the site (Figure 2) are $15 \mathrm{~m}(\sim 50 \mathrm{ft}$.) long by $3 \mathrm{~m}(\sim 9 \mathrm{ft}$.) deep by $0.6 \mathrm{~m}(2 \mathrm{ft}$.) wide and

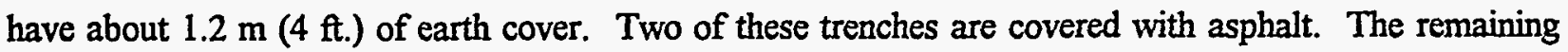
trenches are described as being $30 \mathrm{~m}$ long $(\sim 100 \mathrm{ft}$.), 6-7 $\mathrm{m}(20-24 \mathrm{ft}$.) deep and $2 \mathrm{~m}(6 \mathrm{ft}$ ) wide with $1.2 \mathrm{~m}$ (4 ft.) of earth cover.

The KAFB RB-11 landfill was used to dispose of laboratory wastes (gloves, wipes, etc.) and animal carcasses that had received varying exposure doses of radiation as a result of military research activities carried out in the 1960s and early 1970s. Most of the radioactivity was in the form of induced activity and short-lived radionuclides. However, based on interviews with former employees who worked at the site, it is likely that several millicuries of radionuclides with longer halflives are present, e.g., ${ }^{137} \mathrm{Cs}\left(\mathrm{t}_{1 / 2}=30 \mathrm{yrs}\right)$, ${ }^{90} \mathrm{Sr}\left(\mathrm{t}_{1 / 2}=28 \mathrm{yrs}\right)$. Only a small portion of the waste appears to have been buried in drums. In addition to the radioactive wastes, an undetermined amount of hazardous and toxic liquid wastes may also have been disposed of in the trenches. These included small amounts of acids, mercury, cyanides and silver.

The purpose of this paper is to describe a case study in which traditional site characterization methods currently approved by Environmental Protection Agency (EPA), such as grid drilling and off-site laboratory analysis, are compared with an innovative approach that combines sample optimization with real-time field screening. The innovative approach achieves similar results but is considerably more costeffective and time-efficient because fewer boreholes need to be drilled and fewer samples need be collected and analyzed off-site. In addition, the sample optimization strategy employed allows real-time decisions to be made in the field regarding additional sampling, thus obviating the need for more costly supplemental sampling programs during a revisit of the site.

Our aim is to present an alternative site characterization methodology that is equivalent to meeting the information needs of a regulatory-driven program, while being more efficient than traditional methods. We consider the present study to be a first step in demonstrating this new approach. Further, similar investigations will be necessary to demonstrate that data quality objectives Quality Assurance/Quality Control (QA/QC), statistical validity, and regulatory satisfaction can be achieved at a broader spectrum of sites. 


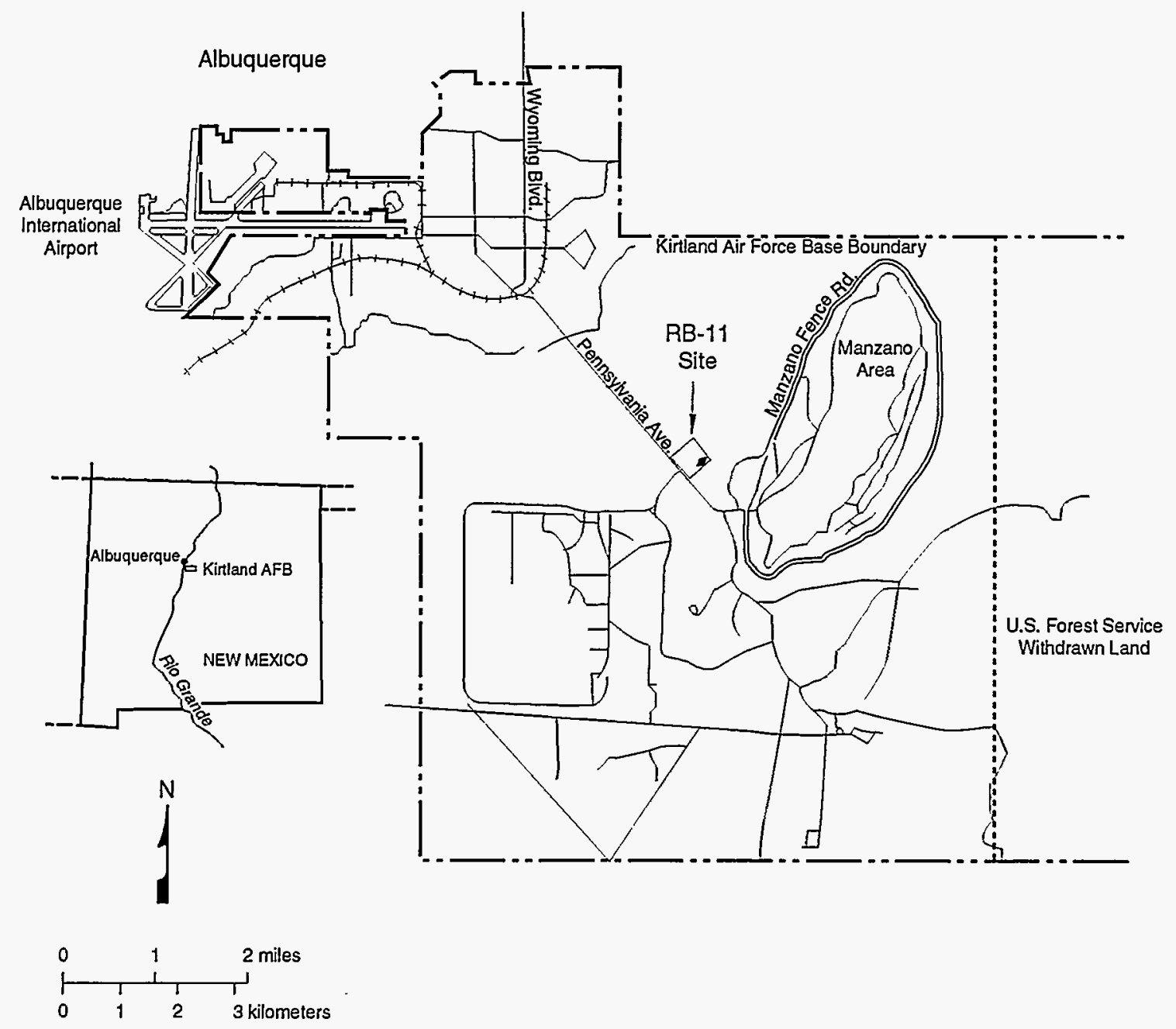

TRI-6621-118-0

Figure 1. Location of RB-11 Mixed Waste Landfill, Kirtland Air Force Base, New Mexico. 

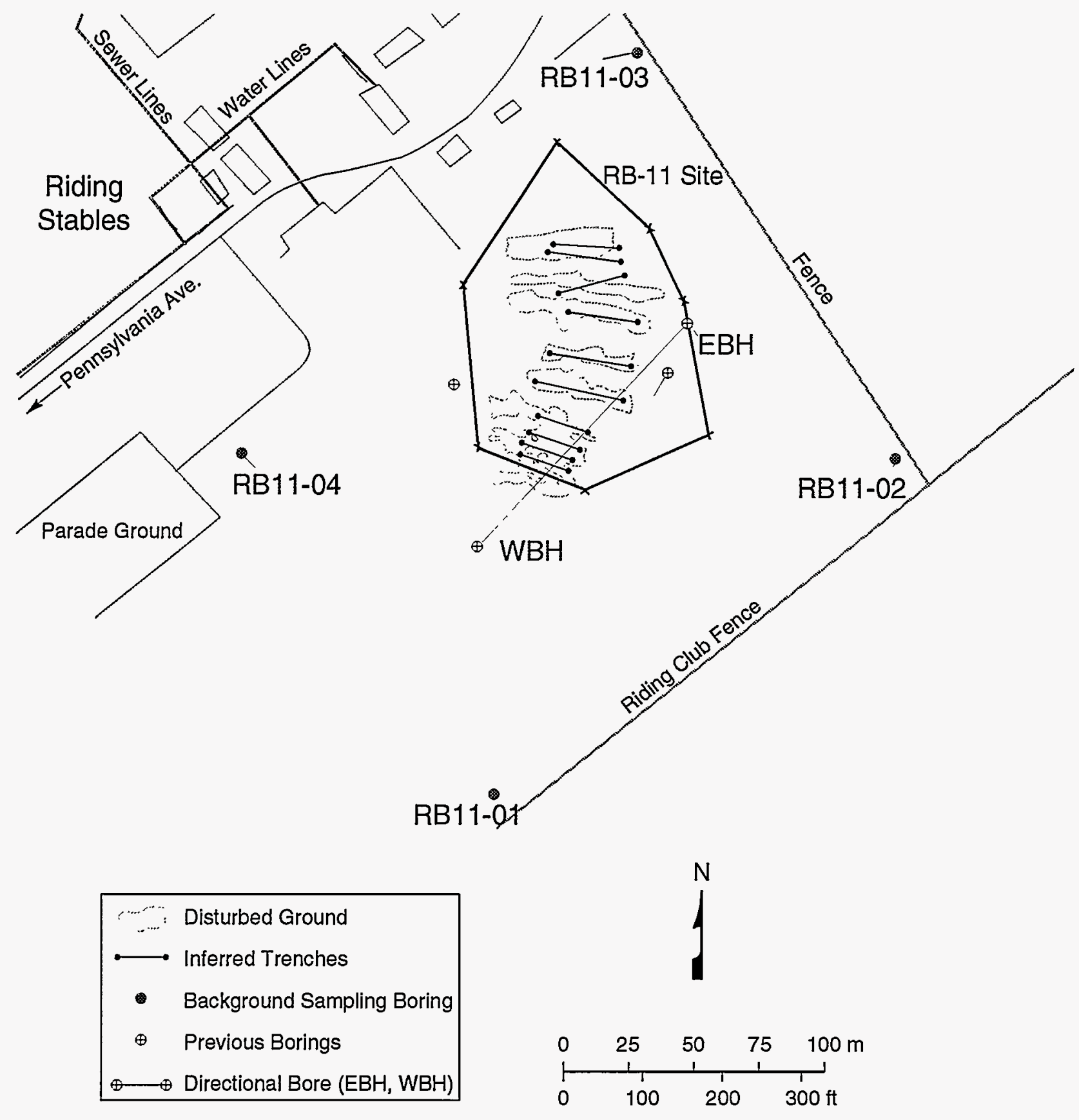

TRI-6621-119-0

Figure 2. RB-11 Site showing infrastructure, inferred location of waste trenches and surrounding disturbed ground. Background sampling points are shown at perimeter (RB11-1 through RB11-4). 


\section{PREVIOUS STUDIES: KAFB RCRA INVESTIGATION}

The U.S. Air Force is responsible for implementing a final remediation action for the RB-11 site as required by the RCRA and under the Air Force Installation Restoration Program. Previous investigative activities at the RB-11 site are summarized in an EPA-approved Stage 2B Work Plan for Kirtland Air Force Base, New Mexico (U.S. Geological Survey, 1993). In addition, the KAFB RB-11 site was the focus of a minimally intrusive field demonstration of innovative site characterization technologies carried out by Sandia National Laboratories (SNL) in 1993 (Floran, 1994). None of these previous investigations conclusively identified any type of contamination at the site.

In July 1994, the Air Force Environmental Management Division and their contractor, Halliburton NUS, conducted a RCRA Facility Investigation (RFI) at KAFB RB-11 to fulfill requirements of their Part B Permit. The results of that investigation (Halliburton NUS - Draft, 1994) are briefly summarized here.

Conventional geophysical surveys including ground penetrating radar and EM-31/61 electromagnetic surveys were used in the RCRA investigation to define nine irregular trench areas, called "disturbed areas". These data were also used to choose locations for subsurface soil sampling, which was subsequently carried out with a Geoprobe $囚$ soil sampler. The objective of the sampling was to define the extent of contaminant migration, if any, away from the disturbed areas. As required by the Air Force, sampling locations were carefully chosen so that they were outside of the disturbed zones to prevent penetration of contaminant sources within the trenches.

After initial field screening, each soil sample was analyzed in an off-site laboratory for gross alpha and beta radiation; ${ }^{226} \mathrm{Ra}$ and ${ }^{228} \mathrm{Ra}$; volatile organic compounds (VOCs); semi-volatile organic compounds (SVOCs); cyanide; metals (including mercury); and petroleum hydrocarbons. The RCRA investigation concluded that there has been no significant migration of contaminants (organics, metals, radiation) away from the trenches. However, if a release not detected by field screening had been identified, the Air Force was prepared to revisit the site and conduct a detailed follow-up sampling program.

Over a span of 13 days, 36 boreholes were drilled and 163 soil samples were collected and sent to an off-site laboratory for analysis. These numbers do not include surface soil samples collected, additional drilling and sampling carried out for the EPA, and QA/QC samples that were required by RCRA (duplicates and blanks). If the latter activities were eliminated the total operation would have probably taken about 11 days. It should be noted that the Stage 2D-1 RFI report revealed that radiation levels averaged slightly above background adjacent to one trench, although the data were insufficient to verify that radiological migration has taken place (Halliburton NUS - Draft, 1994). In addition, trace amounts of mercury were detected in soil samples near three trenches, suggesting that limited migration of this metal may have occurred at the site. 


\section{ADAPTIVE SAMPLING INVESTIGATION}

The Adaptive Sampling field demonstration took place during the first week in August 1994, approximately a week after completion of the RCRA investigation. The primary objective was to demonstrate that an Adaptive Sampling methodology that combines real-time field screening results with sample optimization could do an equivalent or better site characterization than could be achieved by using a conventional approach. The traditional type of site characterization often involves grid sampling, a heavy reliance on costly off-site analyses, and multiple site visits and sampling programs. To accomplish this objective, the Adaptive Sampling plan was compared with the conventional work plan carried out by the Air Force. To make the comparison as realistic as possible, the same drilling contractors, Halliburton NUS, and the same sampling equipment, Geoprobe $囚$, were used in both investigations. Off-site laboratory analyses closely matched those specified in the KAFB Work Plan. The main objective of the analytical work performed during the investigation was to provide data that could be reliably compared with similar data obtained by the Air Force RCRA investigation.

There were significant differences in the way the two efforts were carried out. The Air Force followed the required conventional approach of collecting soil samples, conducting field screening (for organics and radiation only), and sending each sample to an off-site contract laboratory for confirmatory analysis as required by EPA in the RFI Work Plan. The RCRA investigation resulted in a four to six-week delay between collection of samples and obtaining analytical results. This time gap was potentially crucial because if any of the samples were found to be contaminated, an expensive follow-up investigation involving a new phase of sampling would have had to be conducted. Although both investigations employed field screening methods, the Adaptive Sampling strategy planned to use these results to obtain additional samples immediately if contamination were encountered, thus saving the added costs of revisiting the site.

A second major difference between the two investigations involved the number of samples collected. The modified RFI Work Plan, which addressed all EPA requirements, called for sampling every 5 feet to the bottom of each trench and also 10 feet below each trench. If contamination was encountered, sampling would continue every $3 \mathrm{~m}(10 \mathrm{ft}$.) until no further contamination was detected. A site characterization can be performed quicker and with fewer samples compared to a conventional RCRA characterization, yet achieve a similar level of confidence regarding potential migration of contaminants, by using Plume ${ }^{\mathrm{TM}}$, a geostatistical-based computer program. 


\section{APPLICATION OF THE ADAPTIVE SAMPLING METHODOLOGY}

Plume $^{\mathrm{TM}}$, a geostatistical-based computer program, and the Adaptive Sampling strategy were used to optimize drilling and sampling locations. Plume ${ }^{T M}$ was developed at Argonne National Laboratory and is a module of SitePlannerTM, a data management and display program marketed by Consolve, Inc. It is currently used by many government laboratories and private industry. Twenty-eight borehole locations were sited adjacent to the disposal trenches using Plume ${ }^{\mathrm{TM}}$. Sampling locations were numbered sequentially from roughly south to north beginning with S1 at the southwest and ending with S28 at the northeast (Figure 3). None of the bores drilled directly into the disturbed areas, which was also the case with the conventional RCRA investigation.

Plume TM combines Bayesian analysis with geostatistics to assist in the location of sampling points. A more complete description of Plume's ${ }^{\mathrm{TN}}$ methodology can be found in Johnson, 1993. Bayesian analysis allows a quantitative merging of "soft" information for a site with hard sampling data. Soft information can include historical records, aerial photographs, non-intrusive geophysical survey results, etc. This kind of information is used to form an initial conceptual image regarding the probable location and extent of contamination. Plume ${ }^{T M}$ uses indicator geostatistics to update and refine the conceptual image as hard sample data become available. Indicator geostatistics allow one to interpolate from areas where samples exist to areas where samples are absent. New sampling locations can then be selected so that the uncertainty associated with contamination extent is minimized.

At KAFB RB-11, the soft information available consisted of aerial photos; anecdotal information regarding the number, size, location, and content of each trench; and several non-intrusive geophysical survey results for the site. This information was used to construct a conceptual image of the contamination at the site. Figures 3 and 4 show a plan view and cross-section, respectively, of this conceptual image in which soils are gray-scale coded, ranging from white (highly unlikely that contamination is present) to black (contamination known to exist). Most of the site appears as variations of gray, since relatively little hard sampling data were available at the outset.

The conceptual image served as the basis for both the RCRA sampling program as well as the program designed with Plume ${ }^{\mathrm{TM}}$. The sampling strategy for the two investigations was the same: sample as close to trenches as possible without actually penetrating them to determine the likelihood that lateral and/or vertical contaminant migration has taken place. In the case of the RCRA sampling program, soil bore locations were based on a modified grid pattern, with one set of soil bores located west of the trenches, four bores to the east of the trenches and the remainder between the trenches (Figure 3).

Soil bore locations (Figure 3 ) were selected incrementally with the aid of Plume ${ }^{\text {TM }}$ for the Adaptive Sampling program, so that information gain was maximized. Information gain was defined as maximizing the volume of soil in the vicinity of the RB- 11 trenches that could be classified as clean at an $80 \%$ certainty level. This definition of information gain was equivalent to the stated objective of the RCRA investigation, which was to determine whether contaminant migration had occurred away from the trenches. RCRA 


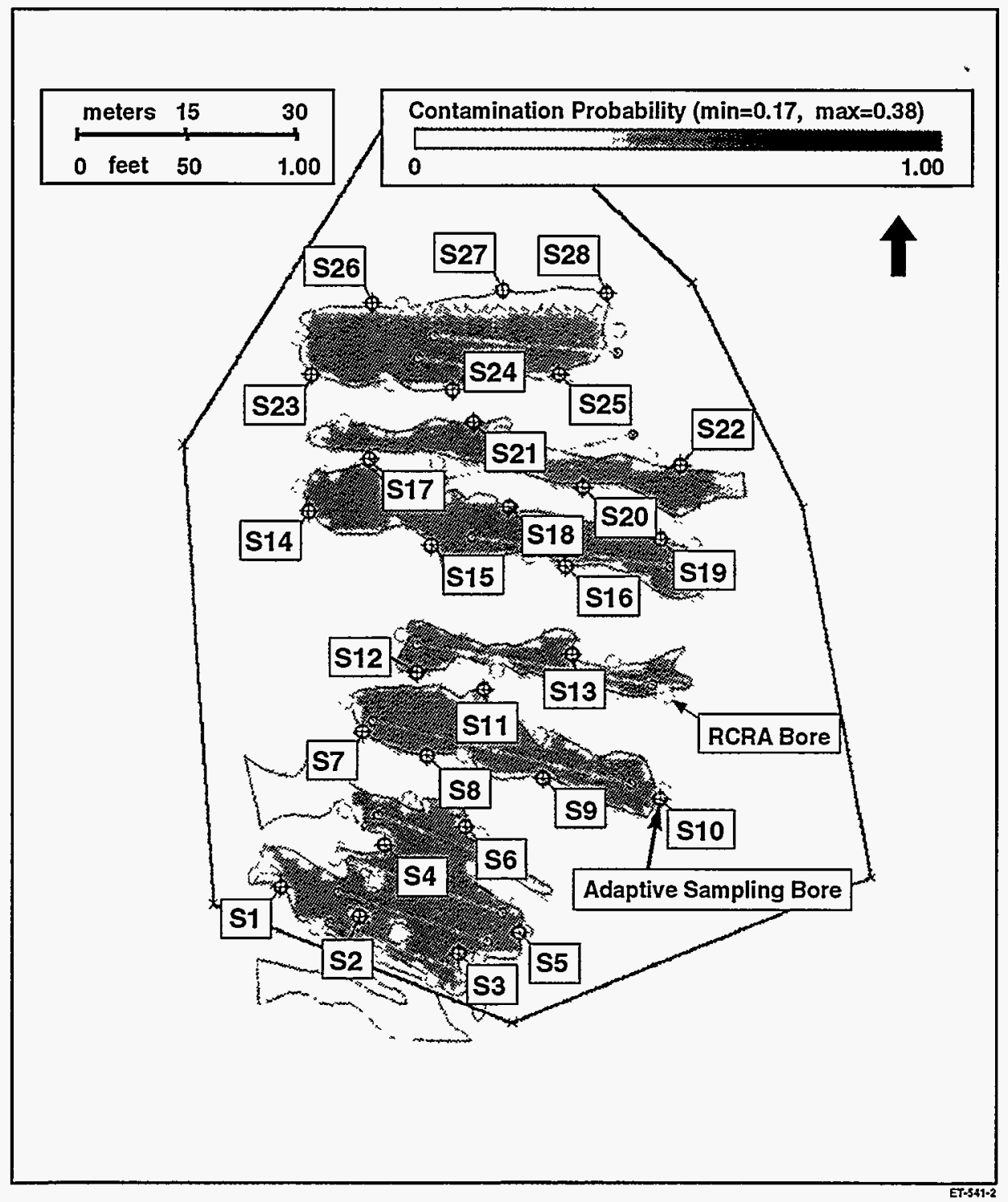

Figure 3. Plan view of RB-11 conceptual model with the locations for Adaptive Sampling and RCRA soil bores. 


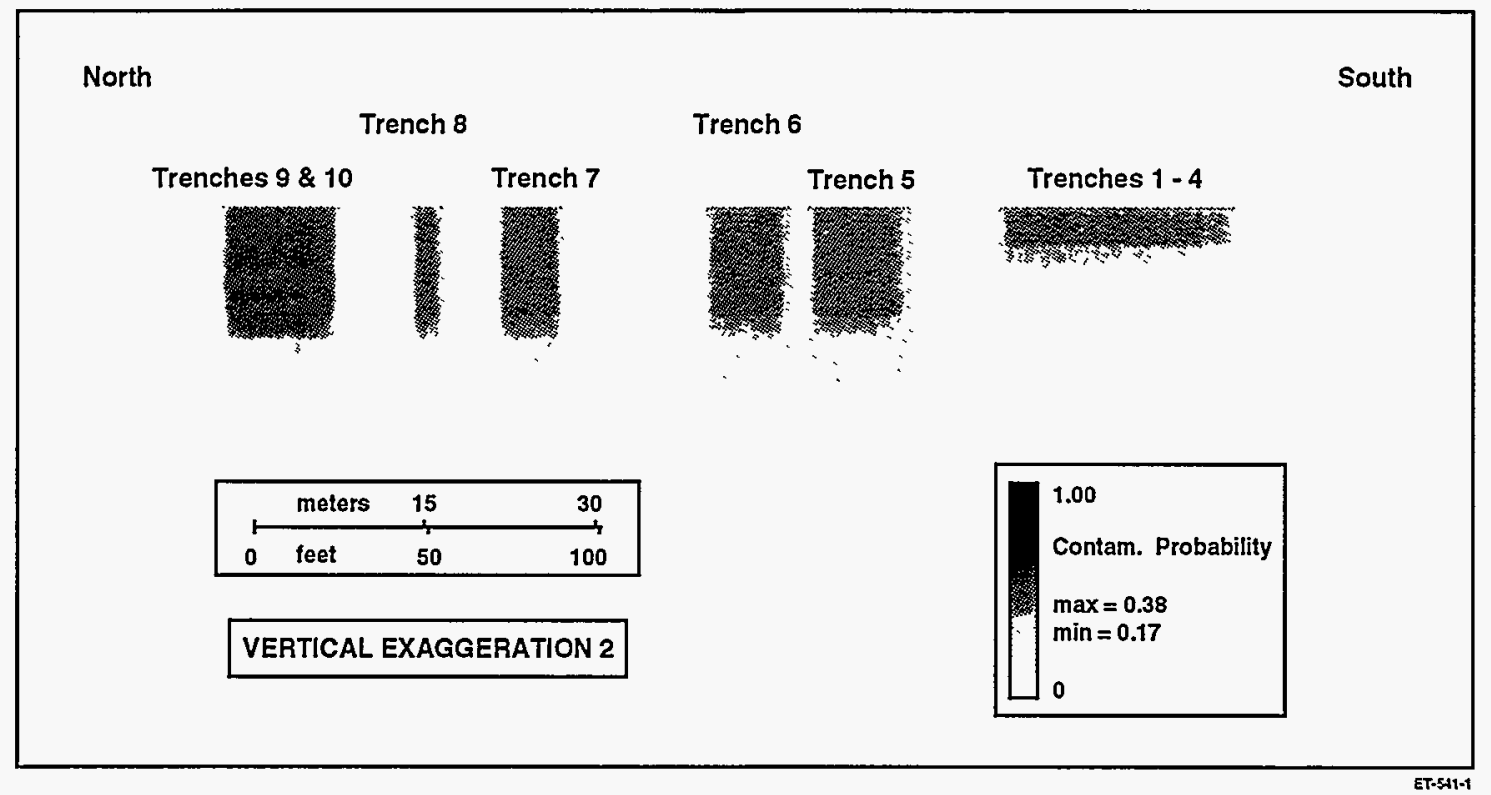

Figure 4. North-South cross-section of RB-11 conceptual model 
investigations never completely remove uncertainty regarding the nature and extent of contamination. The level of uncertainty that can be tolerated during a traditional characterization activity has not been specified by the EPA. For the purposes of this comparison, an $80 \%$ certainty level was chosen.

The information expected from the RCRA sampling program using the $80 \%$ certainty level was evaluated by assuming that the samples would have yielded "clean" results. These samples were used to update the initial conceptual image and measure the volume of soils that would be classified as clean. Locations for the Adaptive Sampling effort were then selected to provide the same information gain, while keeping the number of bores and sampling locations to a minimum. The assumption of clean samples reflects the best possible outcome from the conventional investigation and provides confirmation that contaminant migration has not taken place.

In the first phase of the Adaptive Sampling program, enough soil bore locations were selected to provide the same base amount of information as expected from the conventional investigation. Because of the field analytical methods employed by the Adaptive Sampling program, analytical results for radiation and VOC analyses were available the same day that bores were drilled, while most of the metals analyses were available before the end of the first phase. Based on these results, the conceptual site model was updated using Plume ${ }^{\mathrm{TM}}$. If contamination had been encountered, a second phase of sampling would have immediately ensued, with Plume ${ }^{\mathrm{TM}}$ providing the locations of new bores. Additional soil bores and sampling would have continued until the contamination extent had been fully characterized. 


\section{FIELD PROCEDURES}

\section{Background Sampling}

Prior to the field demonstration, four subsurface soil samples were obtained for background determination of organic compounds, metals and radiation. The samples were collected using a Geoprobeß at various depths between 5 and $8.5 \mathrm{~m}$ (16-28 ft.) from areas known to be uncontaminated near the periphery of the site, approximately $90-120 \mathrm{~m} \mathrm{(} 300-400 \mathrm{ft}$.) from the ends of the closest trenches (Figure 2). These background samples were analyzed on-site by field screening methods and also in offsite laboratories. The data were used to help formulate a sampling strategy for the demonstration.

A procedure was designed to minimize the amount of material needed for both on-site field screening and off-site analysis. Each soil sample was divided into five splits; three of these were used initially for field screening, and two were sent off-site (Figure 5). In addition, one of the splits used for radiological screening was also sent to an off-site laboratory for isotopic uranium and thorium determinations. This same procedure was followed during the main sampling phase of the investigation in August.

\section{Drilling}

During the August demonstration, 81 soil samples were collected at depth using two Geoprobeß soil samplers which operated simultaneously in the field. The Air Force also used the same two Geoprobes( during their field sampling. Twenty-two of the 28 borehole locations were sampled at approximately 3,6 and $9 \mathrm{~m}(10,20$ and $30 \mathrm{ft}$.) below the surface, while the remaining six holes were sampled at depths of 3 and $6 \mathrm{~m}$ (10 and $20 \mathrm{ft})$. Three additional samples were obtained including two field replicates.

\section{Field Screening Methods}

On-site field screening of soil samples for radioactivity and volatile organics was obtained within minutes of bringing the samples to the surface. Similar screening for metals took longer but a substantial number of samples were analyzed prior to the end of the field work.

Field screening instrumentation included a photoionization detector (PID) for headspace analysis of organic vapors; a Geiger-Muller (GM) radiation instrument with an internal sodium iodide detector and pancake probe for gamma radiation; and $\mathrm{x}$-ray fluorescence (XRF) analysis for metals. Soil samples were also scanned for alpha radiation using a scintillometer and beta radiation using a second GM tube. Field screening methods were employed sequentially, with headspace done first to minimize loss of volatile organics. In addition to headspace and gross alpha/beta and gamma detection, a full gamma-ray spectral scan of a split from each sample to be sent off-site was performed within several hours of sample collection 
(Figure 5). Metals analysis by XRF was available within 24 hours. These analyses were done at SNL in a nearby laboratory three miles away, but for the purposes of this study, are considered to have been done "on-site". It should be stressed that the laboratory XRF unit is field transportable and could have been operated at the KAFB RB-11 site within a mobile lab. During background sampling, which preceded the field demonstration, XRF analyses were obtained in one hour. Quick turn-around time for metals was achieved by eliminating a time-consuming grinding step during sample preparation. Previous results using this innovative method have been shown to be reasonably accurate at identifying anomalous samples during field screening (Floran, 1993). Such a rapid analysis strategy ensured quick determination of potential contamination at a particular drilling location. 


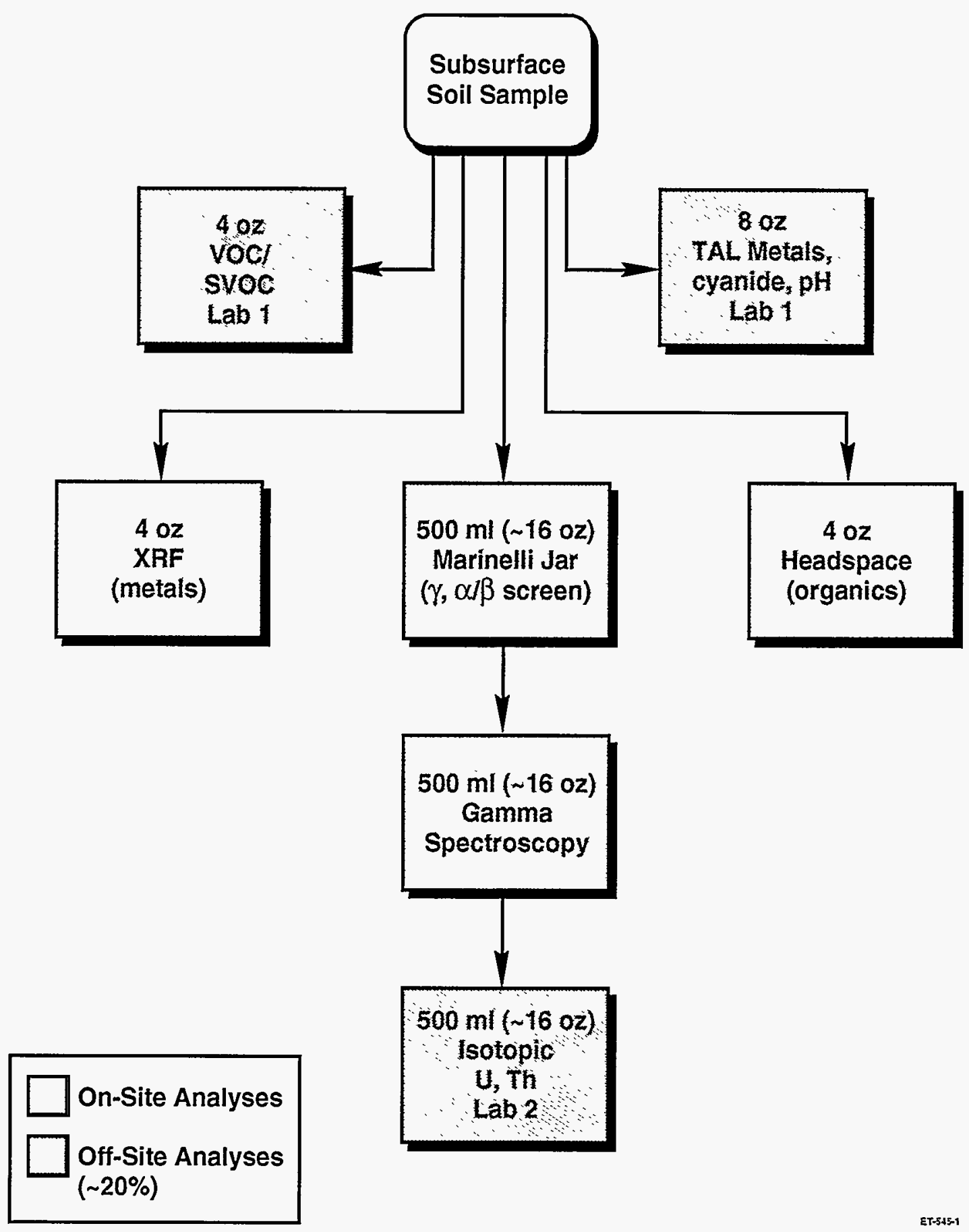

Figure 5. Flow diagram illustrating how splits from each subsurface soil sample were allocated for on-site field screening and off-site laboratory analyses. 


\section{RESULTS}

\section{Field Screening}

No elevated values above background readings were obtained. All headspace values were $0 \mathrm{ppm}$ (action levels were set at $10 \mathrm{ppm}$ ). XRF results were below RCRA action levels for all metals analyzed. Gamma radiation counts on each soil sample were below background plus two standard deviations, which was the action level used to identify radiological contamination.

\section{Laboratory Analytical Results}

Approximately $20 \%$ of the total number of soil samples collected were sent to off-site laboratories for confirmatory analyses. These included 15 samples plus two field replicate QA/QC samples. Separate splits of each sample (including background samples) were analyzed for a complete suite of organic compounds, metals and radioactivity. These included 34 volatile organic compounds, 67 semi-volatile species, 23 metals (Target Analyte List [TAL] metals plus mercury), three uranium isotopes, two thorium isotopes, cyanide, and $\mathrm{pH}$. In addition, 73 radionuclide species were analyzed in an on-site laboratory at Sandia by gamma-ray spectroscopy. The tabulated laboratory data may be found in Appendix A.

\section{VOCs, sVOCs}

Two volatile organic compounds, methylene chloride and toluene, were detected in a majority of the soil samples; acetone was found in just three samples. All of these occurrences were below human health risk based (HHRB) standards, as defined by the Air Force's RCRA investigation (Halliburton NUS Draft, 1994). The presence of methylene chloride and acetone are likely to be the result of laboratory contamination. Both compounds were noted in laboratory blanks. In addition, methylene chloride was also found in equipment and trip blanks. Toluene ranged from below detection to $22 \mu \mathrm{g} / \mathrm{kg}$, well below the HHRB action level of $1.6 \times 10^{7} \mu \mathrm{g} / \mathrm{kg}$.

Six semivolatile compounds were detected in the KAFB RB-11 soils, all below action levels. One compound, phenol, was found in every sample and another, bis(2-Ethylhexyl)-phthalate, was detected in most samples. The majority of these occurrences were near or below the reporting limit although in one sample, phenol had a concentration of $1700 \mu \mathrm{g} / \mathrm{kg}$. The presence of bis(2-Ethylhexyl)phthalate was noted in the equipment blank. Trace quantities of benzoic acid, chysene and benzo(b)fluoranthene were detected in one sample each, and di-n-ocylphthalate was found in two samples, all at levels below reporting limits. 


\section{Metals}

Only one metal, beryllium, was detected above its action level. All of the samples exceeded this concentration $(0.2 \mathrm{mg} / \mathrm{kg})$, ranging from 0.28 to $0.64 \mathrm{mg} / \mathrm{kg}$. These levels of beryllium are typical of the relatively high background values within the area being investigated (Halliburton NUS - Draft, 1994).

\section{Other (Cyanide; Soil pH)}

No evidence of hydrogen cyanide or any other metallic salts of hydrocyanic acids were found. Two samples reported cyanide concentrations at or slightly above the reporting limit $(0.5,0.7 \mathrm{mg} / \mathrm{kg})$. The action level for cyanide is $2000 \mathrm{mg} / \mathrm{kg}$. Soil $\mathrm{pH}$ ranged from 8.4 to 9.5 .

\section{Radiological Compounds}

Three isotopes of uranium $\left({ }^{233 / 234} \mathrm{U},{ }^{235} \mathrm{U},{ }^{238} \mathrm{U}\right)$ and two isotopes of thorium $\left({ }^{230} \mathrm{Th},{ }^{232} \mathrm{Th}\right)$ were analyzed in an off-site laboratory. Ranges for the uranium isotopes were $0.82-4.8 \mathrm{pCi} / \mathrm{g}\left({ }^{233 / 234} \mathrm{U}\right), 0.021-$ $0.11 \mathrm{pCi} / \mathrm{g}\left({ }^{235} \mathrm{U}\right)$, and $0.74-4.4 \mathrm{pCi} / \mathrm{g}\left({ }^{238} \mathrm{U}\right)$. Thorium isotopes ranged from $0.59-1.4 \mathrm{pCi} / \mathrm{g}\left({ }^{230} \mathrm{Th}\right)$ and $0.5401 .4 \mathrm{pCi} / \mathrm{g}\left({ }^{232} \mathrm{Th}\right)$. none of these values are appreciably above background values determined for the site (C. Adams, Capt., USAF, personal communication, 1994).

Radiological contaminants of concern at KAFB RB-11 include the source radioisotopes, ${ }^{90} \mathrm{Sr}$ and ${ }^{137} \mathrm{Cs}$. ${ }^{90} \mathrm{Sr}$ was not determined. The isotope ${ }^{137} \mathrm{Cs}$ was measured during the field screening phase of the Adaptive Sampling investigation but no values above background were recorded. Analysis of these radioisotopes was not required by the EPA-approved Work Plan, although gross beta determinations provided an indirect indication that neither was present above background levels (Halliburton NUS - Draft, 1994).

\section{Data Transfer Using the Adaptive Sampling Methodology}

A SunSPARC workstation at SNL, New Mexico, where the Plume ${ }^{\mathrm{TM}}$ geostatistical program resides (four miles from the KAFB RB-11 site), was successfully linked to an identical workstation at Argonne National Laboratory via the Internet. Communication between the workstations was instantaneous. Data from the KAFB RB-11 site were transmitted by FTP to both workstations in minutes using a cellular phone/modem hookup from the field. If contamination had been encountered during the KAFB RB-11 investigation, we planned to use the Plume ${ }^{\mathrm{TM}}$ software at Argonne to suggest additional sampling locations. In the near future, it is likely that these types of real-time sampling decisions in the field will be possible from remote locations thousands of miles away. 


\section{COST SAVINGS}

Substantial cost savings can be obtained by optimizing the number of samples obtained during a site characterization investigation, as well as by judiciously choosing how many of these should be analyzed off-site. The Adaptive Sampling program resulted in drilling $22 \%$ fewer boreholes, collecting $50 \%$ fewer samples, and analyzing $91 \%$ fewer samples in an off-site laboratory. A synergistic cost savings was possible with the Adaptive Sampling approach because fewer samples were collected (compared to the conventional type of investigation) and only a small fraction of the reduced sample set was analyzed. Of these costs, the most significant savings involved laboratory analyses which typically cost greater than \$1K per sample.

For the analyses performed in this investigation, undiscounted prices per soil sample were as follows: VOCs (\$295), SVOCs (\$585), TAL metals plus mercury (\$466), cyanide (\$65), pH (\$25), isotopic thorium (\$178), and isotopic uranium (\$166). However, discounts of up to $50 \%$ are typically available to long-term customers. Actual costs for the types of analyses done here might range between $\$ 1 \mathrm{~K}(\sim 50 \%$ discount) to $\$ 1.8 \mathrm{~K}$ (no discount) per sample. Thus, there is a tremendous potential for savings in analytical costs if only $20 \%$ of the samples collected are sent to an off-site laboratory, as was done in the present study.

Cost savings achieved by reducing off-site analytical costs must be weighted against additional costs associated with the increased level of effort associated with field screening (labor, depreciation on analytical equipment, report writing, expendables, etc.), as well as the costs associated with the Plume ${ }^{\mathrm{TM}}$ software (acquisition, training, personnel required to run the program). In the Adaptive Sampling program, the major additional field screening cost that was not borne by the Air Force investigation was the use of an XRF unit for metals analysis. However, these costs, estimated to be $\$ 30 / \mathrm{hr}$ or $\$ 1,600$ for the total project (including labor), were minor compared to the savings in off-site analyses. The cost of the SitePlanner/Plume ${ }^{\text {TM }}$ software, which is now available for personal computers (PCs), has been steadily dropping. The present costs including training are approximately $\$ 6 \mathrm{~K}$. 


\section{CONCLUSIONS}

The combination of Adaptive Sampling with field screening enabled our project to achieve a similar level of confidence compared to the conventional investigation regarding potential migration of contaminants away from the trenches. By comparison, the Adaptive Sampling project drilled 28 locations vs. 36 for the Air Force, collected 81 samples vs. 163 for the Air Force, and sent 15 samples vs. the Air Force's 163 to an off-site laboratory for analysis. In addition, the Adaptive Sampling field work took 3 1/2 days compared to the 13 days for the Air Force's RFI. These figures translate into large cost savings: $22 \%$ fewer boreholes drilled, $50 \%$ fewer samples collected, and $91 \%$ fewer samples analyzed off-site. Of these costs, the most significant savings involve laboratory analyses which typically cost greater than $\$ 1 \mathrm{~K}$ per sample for the type of analyses done in the present study.

Despite the large number of samples collectively screened and analyzed in both investigations, no significant contamination above background levels of any kind was found. These results suggest that no gross, systematic migration of contaminants away from the trenches has occurred at the site.

The type of site characterization effort described here, in which geostatistically-based iterative sampling is combined with real-time field screening, is best demonstrated when contamination is present. In such a situation, the value of extensive field screening and avoidance of subsequent sampling phases is more easily quantified. A second phase of demonstration of the Adaptive Sampling methodology at a site with known contamination is scheduled for July 1995. 


\section{REFERENCES}

Floran, R. J. 1993. "Technical and Economic Evaluation of Selected Technologies of the Landfill Characterization System.” ER '93 Environmental Remediation Conference, Augusta, GA. Vol. 2, pp. 1055-1062.

Floran, R. J. 1994. "Technical and Economic Evaluation of the Landfill Characterization System, Part II: Kirtland Air Force Base RB-11 Landfill." Milestone report for the Department of Energy.

Halliburton NUS. 1994. "RCRA Facility Investigation (RFI) Stage 2D-1, Appendix IV-Draft." Prepared for HQ AFCEE/ESR, Brooks AFB, TX.

Johnson, R. L. 1993. "Adaptive Sampling Program Support for Expedited Site Characterization." ER '93, Environmental Remediation Conference, Augusta, GA. Vol. 2, pp. 781-787.

U.S. Geological Survey. 1993. "Installation Restoration Program.Stage 2B Work Plan for Kirtland Air Force Base, New Mexico." USAF Contract No.: AFCEE 91-02. 
APPENDIX A

A-1 


\begin{tabular}{|c|c|c|c|c|c|c|c|c|c|c|c|c|c|c|c|c|c|c|c|}
\hline ON & ON & ON & $\mathbf{O N}$ & $\overline{O N}$ & GN & av & $\mathbf{a N}$ & a & $\mathbf{O N}$ & ON & ON & ON & ON & ON & on & ON & ON & 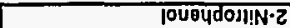 & \\
\hline ON & $\alpha$ & àv & ã & öN & $\alpha$ & wiv & $\underline{a}$ & ầ & ầ & aij & ON & ấ & ÖN & $\overline{\mathrm{aN}}$ & ŌN & $\overline{Q N}$ & on & Güioioúdós! & \\
\hline ON & oiv & $a j$ & a & ai & कN & ow - & ờ & $\ddot{\alpha}$ & ầ & $\sigma^{N}$ & $\ddot{\alpha}$ & के & $-\ddot{\alpha}$ & $\overline{O N}$ & के & ON & an & 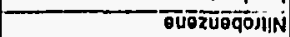 & 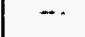 \\
\hline ovi & ä & نَّ & $\dot{\alpha}$ & ă & on. & $\sigma^{*}$ & ä̀ & on & $\ddot{\alpha}$ & $\overline{\mathrm{N}}$ & $\ddot{O N}$ & ôj & $-\sigma$ & ow & an & QN & कN & 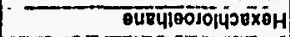 & $\cdots$ \\
\hline ow & $\bar{\alpha}$ & $\ddot{a}$ & $\ddot{q}$ & ồ & $\bar{a}$ & $a$ & an & $\ddot{\alpha}$ & an & $a \mathbf{v}$ & an & $\overline{a N}$ & in & ow & $\bar{\alpha}$ & ON & का & 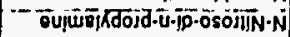 & $\cdots$ \\
\hline ON & कN & QN & ow & ON & QN & an & ON & ON & QN & on & ON & का & ON & ON & ow & ON & ON & 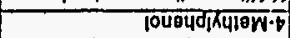 & \\
\hline ON & ài & à & ân & $\bar{\alpha}$ N & ö̀ & $\ddot{\alpha} \mathbf{N}$ & avi & av & $\ddot{\alpha} \mathbf{N}$ & on & Q & àv & “à & ồ & $\bar{\alpha}$ & ON & $\bar{\alpha}-$ & 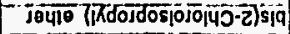 & - \\
\hline añ & $\underline{\alpha}$ & $a \dot{v}$ & $\underline{\alpha} \dot{N}$ & $\underline{w}$ & $a v$ & ov & $\underline{a}$ & on & $\alpha \mathfrak{N}$ & an & ON & $\ddot{\alpha}$ & $\sigma_{N}$ & ON & a òi & a & aN & 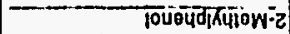 & min \\
\hline an & $\overline{\alpha N}$ & $\underline{9}$ & ä & $\overline{\mathrm{N}}$ & an & $\mathbf{a}^{--}$ & a & aj & âv & $a \mathrm{~N}$ & ON & $a \mathrm{i}^{-}$ & QN & ŌN & $a$ & ON & ON & 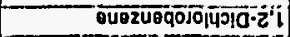 & $\cdots$ \\
\hline on & ON & $\bar{a} \mathbf{N}$ & $\overline{\mathbf{\alpha}}$ & än & an & $\overline{a N}$ & âN & $\bar{\alpha} \mathbf{N}$ & $\bar{a}$ & $\overline{a N}$ & ON & à & aN & on & an & ON & $\overline{O N}$ & 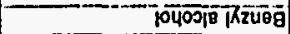 & \\
\hline ON & on & on & $\mathbf{a}$ & ON & an & on & ON & a & $\mathbf{W}$ & $\overline{a v}$ & का & aN & $a_{N}$ & ON & on & ON & ON & 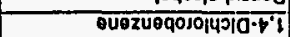 & \\
\hline â & ö̀ & $\overline{\mathrm{aN}}$ & ầ $\cdots$ & ơv & $\overline{a N}$ & $\cdots a^{\prime} \cdots$ & â & $a \bar{N}$ & $\bar{\alpha}$ & ồ & ON & â & ON & on & - ầ & ON & $\ddot{O N}$ & 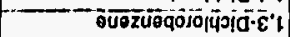 & $\cdots$ \\
\hline $\bar{\alpha}$ & $a v$ & $\bar{\alpha} \mathbf{N}$ & $\overline{a n}$ & an & क & $\bar{a} \mathbf{j}$ & an & $\bar{\alpha} \mathbf{N}$ & on & $-a$ & ON & ôi & ON & $\mathrm{ON}^{-1}$ & $\bar{\alpha}$ & ON & $\widetilde{O N}$ & 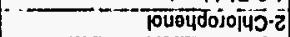 & 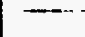 \\
\hline$\ddot{\alpha}$ & ON & ài & $\overline{\mathbf{O N}}^{-}$ & $\overline{O N}-$ & $\overline{Q_{N}}$ & a & $\mathbf{a}$ & añ & $\ddot{\alpha}$ & $a \bar{N}$ & ẩ & on & $=\ddot{O N}$ & ồ & कर & on & $\sigma \mathrm{N}$ & 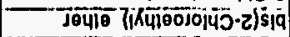 & \\
\hline oir & $0 \angle Z^{-}$ & $06 !$ & $\overline{O S E} \overline{-}$ & OSII & 091 & 018 & ozt & $0 E$ & $-\overline{0 \bar{b}}$ & $=002 i$ & $\overline{0.99}$ & $062^{-}$ & - $08 r$ & $09 \bar{\varepsilon}-$ & ois & ozs & " & pü & $20 \mathrm{AS}$ \\
\hline 20 & 26 & 96 & 86 & $\frac{96}{18}$ & 00 & 26 & .66 & 86 & 66 & 001 & 86 & 96 & 66 & 96 & .06 & 26 & 86 & 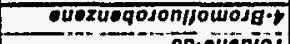 & \\
\hline LE & 20 & sol & 201 & 26 & rot & 00 & -60 & 001 & 80 & 68 & 001 & $\tilde{9} \tilde{6}$ & 001 & $6 \overline{6}$ & 66 & 001 & 9001 & op-öūonjōi & m- \\
\hline Toeñosisis & Tonosog & $\operatorname{Aon} 050 y$ & X & xका & $1000025 y^{\circ}$ & 7xionosogy & хбойово & $\pi 60$ oso. & 7000̄osoü & Xonosö & 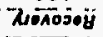 & 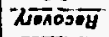 & zionosoty & $200 \overline{0}$ & Xioñosey & 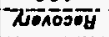 & रविक्ष & 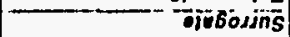 & - \\
\hline ON & on & ON $^{-}$ & $\bar{a}$ & कN & ON & on & $\overline{\mathbf{O} N}$ & $\square_{\bar{N}}$ & $a^{N}$ & $\overline{a N}$ & $\overline{O N}$ & का & an & ON & -ō & ON & क N & 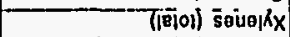 & $\cdots$ \\
\hline$\overline{\mathbf{O N}}$ & $\bar{\alpha} \mathbf{N}$ & â & का & $\overline{O N}$ & ON & aN & $\mathbf{a} \mathbf{N}$ & $\bar{\alpha}$ & $\overline{\mathbf{N}}$ & $\overline{O N}$ & ON & $a \mathfrak{i v}$ & $-a^{\prime}$ & $\overline{O N}-$ & ố & ON & $\overline{O N}$ & 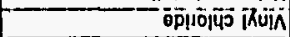 & \\
\hline ON & On & a & GN & a & ow & $\mathbf{a}$ & $\mathbf{a}$ & an & on & $\mathrm{aN}$ & ON & ON & GN & ON & $a N$ & ON & ON & 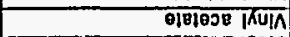 & \\
\hline$\overline{O N}$ & $\overline{\mathrm{aN}}$ & a & $\bar{N}$ & an & aN & $\bar{\sigma}$ & ai & $\underline{\mathbb{N}}$ & $\underline{\underline{N}}$ & $\overline{a N}$ & aN & a & ä & $\mathrm{ON}^{-}$ & ä & ON & $\overline{d N}$ & 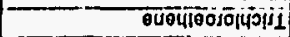 & \\
\hline $\bar{\alpha}$ & ö & क & कN & $\sigma_{N}$ & का & $\bar{a}$ & ai & $\bar{a}$ & on & $\sigma^{N}$ & $\overline{O N}$ & $-\bar{a}$ & ON & ÔN & ố & ON & $-\overrightarrow{O N}$ & Оपष्ष & \\
\hline $\bar{\alpha}$ & $\overline{\alpha i n}$ & $-\frac{a}{\alpha i}$ & an & $\mathbf{O N}^{-}$ & कN & के & $\mathbf{O N}$ & ồ & $\alpha^{N}$ & â & ONN & $\overline{\mathbf{N}}$ & $\cdots \overline{O N}$ & ON- & 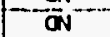 & ON & ON & 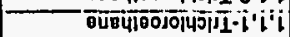 & \\
\hline$\overline{z z}$ & $\overline{O N}$ & ON & $\overline{2}$ & $\sqrt{16}$ & an & 82 & $8 \div 9$ & 2 & $E \%$ & W & ON" & - & ÖN & $\bar{\varepsilon} i^{-}$ & $\bar{\xi} i$ & si & ON & อบอักติ & \\
\hline ON & ON & $\mathbf{a}$ & an & an & $\mathbf{W}$ & a & $\mathbf{a N}$ & $\mathbf{a}$ & $\mathbf{W}$ & an & ON & on & ON & ON & ON & ON & ON & 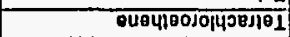 & \\
\hline on & $\overline{\mathbf{o n}}$ & क & a & aN & ow & $\bar{a}$ & $\mathbf{a}_{\mathbf{N}}^{--}$ & $\bar{W}$ & $\overline{\mathbf{N}}$ & $a \bar{N}$ & $O N$ & $\bar{\alpha}$ & GN & ON & $\because \overline{\mathrm{ON}}$ & $\overline{a N}$ & ON & 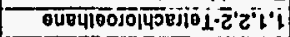 & \\
\hline ois & $\omega^{\prime}$ & a & क & oN & के & an & à & on & $\overline{a n}$ & $-\bar{\alpha} \dot{\hat{N}}$ & ON & क् & ON & $-\overrightarrow{\mathrm{NN}}$ & $\overrightarrow{\mathbf{a}}$ & $\bar{a}$ & $\widetilde{O N}$ & 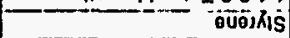 & \\
\hline ON & on & $\bar{\alpha}$ & ON & ON & on & $\bar{a}$ & $\overline{\mathbf{N}} \cdots$ & $a \mathrm{~N}$ & $\overline{\mathbf{a N}}$ & $-\overline{a_{N}}$ & ON - & ON & a & ON & $\bar{\alpha} \bar{N}$ & " & ON & 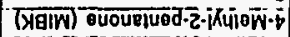 & \\
\hline$[\cdot i$ & 5T & 9.1 & 01 & $\mathbf{a} \mathbf{N}$ & $\overrightarrow{E E}$ & ZE & $\bar{\varepsilon}$ & ${ }^{-} \bar{\varepsilon} \cdot \dot{\varepsilon}$ & $i \bar{\varepsilon}$ & $2 \cdot \overline{6}$ & $i \bar{t}$ & $\bar{z} \bar{\varepsilon}$ & -6 & $\varepsilon$ & $-\bar{c}$ & 5 & $\frac{\pi}{2}$ & 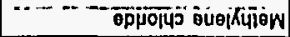 & \\
\hline ON & aN & a & a & aN & an & $\mathbf{a}$ & an & ON & $\mathbf{a}$ & aN & ON & $\omega_{N}$ & ON & an & ON & का & ON & OSOUE $\times 0 \mathrm{H} \cdot \mathrm{C}$ & \\
\hline ợ & $\overline{O N}$ & WN & aN & QN & $\mathbf{a}$ & $\underline{N}$ & $\bar{\alpha}$ & $\vec{\sigma}$ & $\cdots \bar{\alpha}$ & $\overline{a N}$ & ON & ấ & ón & ON & an & $\overline{O N}$ & $\overline{G N}$ & อ̄ūezueqikuig & 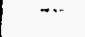 \\
\hline$\ddot{O N}$ & ON & $\bar{\alpha}$ & a & वN & $\overline{\mathbf{O N}}$ & $\bar{\alpha}$ & $\overline{\mathbf{a}}$ & ầ & $\overline{\mathbf{\alpha}}$ & an & ON & à & ON & 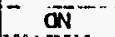 & $\bar{\alpha}$ & ON & $\overline{O N}$ & 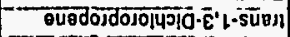 & \\
\hline $\bar{\alpha} \mathbf{N}$ & $\overline{O N}$ & - $\overline{\mathbf{\alpha}}$ & â & $\bar{a}$ & $\bar{a}$ & $\bar{a}$ & $\bar{a} \mathbf{N}$ & $\bar{\alpha}$ & $\bar{\alpha} \mathbf{N}$ & ä̀ & ON & $\overline{O N}$ & $\dot{\alpha i N}$ & ầ & $\overline{O N}$ & ôN & $\overline{\text { ON }}$ & 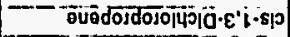 & \\
\hline$\overline{O N}$ & oiv - & $-\overline{\mathrm{ON}}$ & a & $\mathbf{a N}^{-}$ & an & $\overline{\mathbf{N}}$ & aN & $\bar{a}^{N}$ & â & on & ờ & $-a \dot{\alpha i v}$ & ON & $-\frac{O N}{Q N}$ & $\cdots$ ồ & ON & ON & 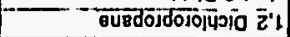 & \\
\hline ON & ON & W & an & ON & $\underline{a}$ & $\mathbf{a N}^{-}$ & aN & oN & $\mathbf{a}$ & a & ON & an & ON & ON & an & ON & ON & 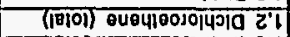 & \\
\hline$\ddot{\alpha}$ & ấ & $-\overline{\mathbf{a}}$ & के & कN & $\mathbf{a}$ & $\overline{a N}-$ & av & $\bar{\alpha}$ & $\bar{\alpha}$ & ầ & ÕN & aN & " & $-\sigma^{-} \cdots$ & ă & ON & $\overline{O N}$ & 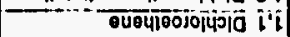 & - \\
\hline ôv & $\bar{\alpha}$ & $-\bar{a}$ & ai & $a \mathrm{~N}^{\circ}$ & क & $\bar{\alpha}^{\cdots}$ & $\cdots a^{-}$ & ô & $\alpha \mathbf{w}$ & $-\vec{a} \mathbf{N}$ & $\overline{O N}$ & $\ddot{\alpha} \mathbf{N}$ & $\cdots$ ôn & - ON & on & ON & aN & 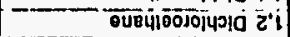 & \\
\hline oiv & WN- & $-\bar{o}$ & कN & $\overline{a N}$ & $\bar{a}$ & $-\overline{a N}^{--}$ & $\because \overline{\mathbf{a}}$ & on & $\because O N$ & $\bar{a} \bar{N}$ & ö & ân & -0 & कN & ấ & $\mathrm{ON}^{-}$ & ON & 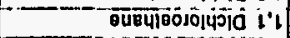 & \\
\hline$\overline{\mathrm{a}} \mathrm{N}$ & aN & $\ddot{\alpha}$ & $-\overline{a N}$ & aN & $\overline{\mathbf{N}}$ & an & $-a \tilde{a}$ & $a \mathrm{~N}$ & -ầ & $a \mathfrak{N}$ & ON & â & $-\frac{O N}{O N}$ & $\cdots$ & के & के & कर & 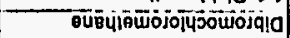 & \\
\hline $\mathbf{Q N}$ & ON & $\mathbf{a N}$ & QN & an & on & an & an & an & $\underline{\mathbf{a}}$ & $\mathbf{a N}$ & ON & $\mathbf{a N}$ & ON & ON & a & ON & ON & 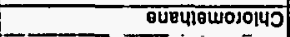 & \\
\hline$\vec{a}$ & âN & $\bar{G}$ & $-\bar{a}$ & $\overline{\mathbf{C N}}$ & a & an & $\overline{\mathbf{a}}$ & $\bar{a}$ & $\overline{\mathbf{w}}$ & $\bar{Q}$ & ầ & aj & ô & ON & ô & on & $\overline{\text { ON }}$ & - iмio,osô̄4Y & - \\
\hline ö̀ & $\mathbf{G}$ & $\overline{\mathbf{a}}$ & ov & $\bar{G}$ & क्ञ & $\bar{\alpha}$ & $=\overline{\mathbf{a}}$ & ôn. & $\overline{\mathbf{\alpha}} \mathbf{j}$ & $\bar{a}$ & ÖN & à & $\tilde{\sigma} \mathrm{N}$ & $\overline{\mathbf{\alpha N}}$ & ầ & ON & on & 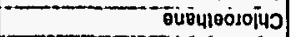 & \\
\hline$\ddot{\alpha}$ & के & $\mathrm{aN}^{-}$ & क & कर & $\overline{\mathbf{a}}$ & के & $-\bar{\alpha} \mathbf{N}$ & wi & ôn. & an - & ô & av & $\tilde{\alpha}$ & $\overline{\alpha N}$ & - ä & ô & $\bar{\alpha}$ & 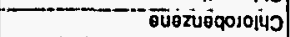 & \\
\hline on & के & क & कर & GN & $\overline{a N}$ & $\bar{a}^{-}$ & ${ }^{n-a}$ or & $\bar{\alpha}$ & ai & $\bar{\alpha}$ & ôN & â & $-\overline{\alpha N}$ & ON & on & कर & $\bar{\alpha}$ & 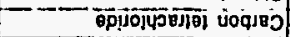 & \\
\hline कN & $\mathbf{O N}$ & ON & av & ON & $\mathbf{a}$ & an & aN & ON & ON & ON & ON & ON & ON & ON & ON & ON & ON & op & \\
\hline ö & $\bar{\alpha}$ & $\overline{Q N}$ & कN & a & a & Ea & $\overline{\mathbf{a}}$ & $\bar{a}$ & an & $\overline{\mathbf{a N}}$ & ờ & a & ON & ờ & on & कN & $T$ & $\cdots($ Y & \\
\hline $\bar{a}$ & $\overline{\mathbf{N}}$ & $\overline{\mathbf{a}}$ & a & $\underline{\underline{N}}$. & an & $\overline{\underline{N}}$ & $\overline{\mathbf{a}}$ & an & $\overrightarrow{\mathbb{N}}$ & $\bar{\alpha}$ & $\overline{\text { ON }}$ & a & $a$ & ON & ầ & $\bar{\alpha}$ & $\overline{\mathbf{O}}$ & 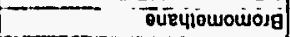 & \\
\hline ơ & $\bar{\alpha}^{-}$ & $\overline{\mathbf{G}}$ & an & $\overline{\mathrm{ON}}$ & w & $-\overline{a j}$ & $\overline{a_{N}}$ & ơn & on & av & ồ & à & âN & an & a & ow & $\mathbf{a N}$ & üjojöwosa & \\
\hline कै & के & कर & a & के & ô & an & $\vec{\alpha} \mathbf{N}$ & $\ddot{\alpha}$ & के & w & ON & ơ & "in & ON & av & ON & $\overrightarrow{O N}$ & 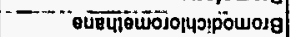 & \\
\hline ON & का & a & on & क & an & on & QN & QN & ON & on & ON & on & ON & ON & ow & W & $\sigma_{N}$ & oūzurg & \\
\hline ô & $\bar{\theta} \cdot \bar{i}$ & $\overline{2}$ & 56 & an & $\overline{a v}$ & on - & $\overline{\alpha N}$ & $\hat{\alpha}$ & â & av & on & $\bar{\alpha}$ N & ON & ON & ai & ồ - & $\overline{z i}_{1}$ & өu010JV & כ0^ \\
\hline Oc-LZS & ol-gzs & $\underset{\text { oz-ris }}{\text { and }}$ & oz-bzs & | oz-zzs & OL-LISS & oz-615 & OE-LLS & OL-9LS & oz-rbs & OE-zts & OL-LIS & 02.65 & $0 \varepsilon-\angle S$ & 0z.ss & $\begin{array}{l}\text { dna } \\
\text { ol-\&s }\end{array}$ & $0 L-\& S$ & $\begin{array}{c}\text { lono1 } \\
\text { punoss } \\
\text {-xove }\end{array}$ & 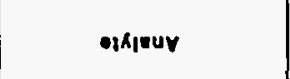 & 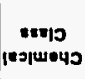 \\
\hline
\end{tabular}




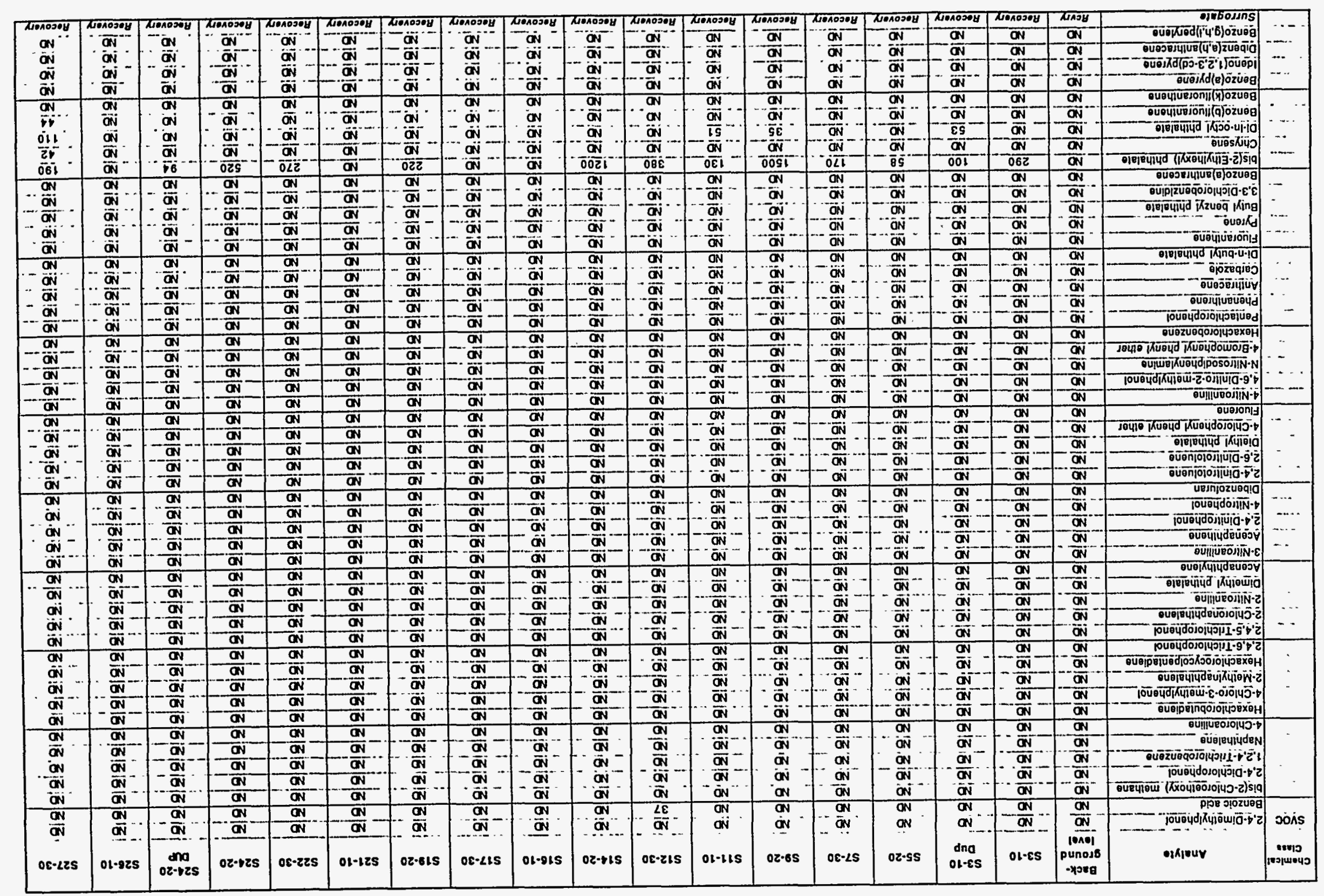


Table 1A - Summary of Reportable Concentrations for Soil Analysis at RB-11 Site Kirtland AFB, New Mexico.

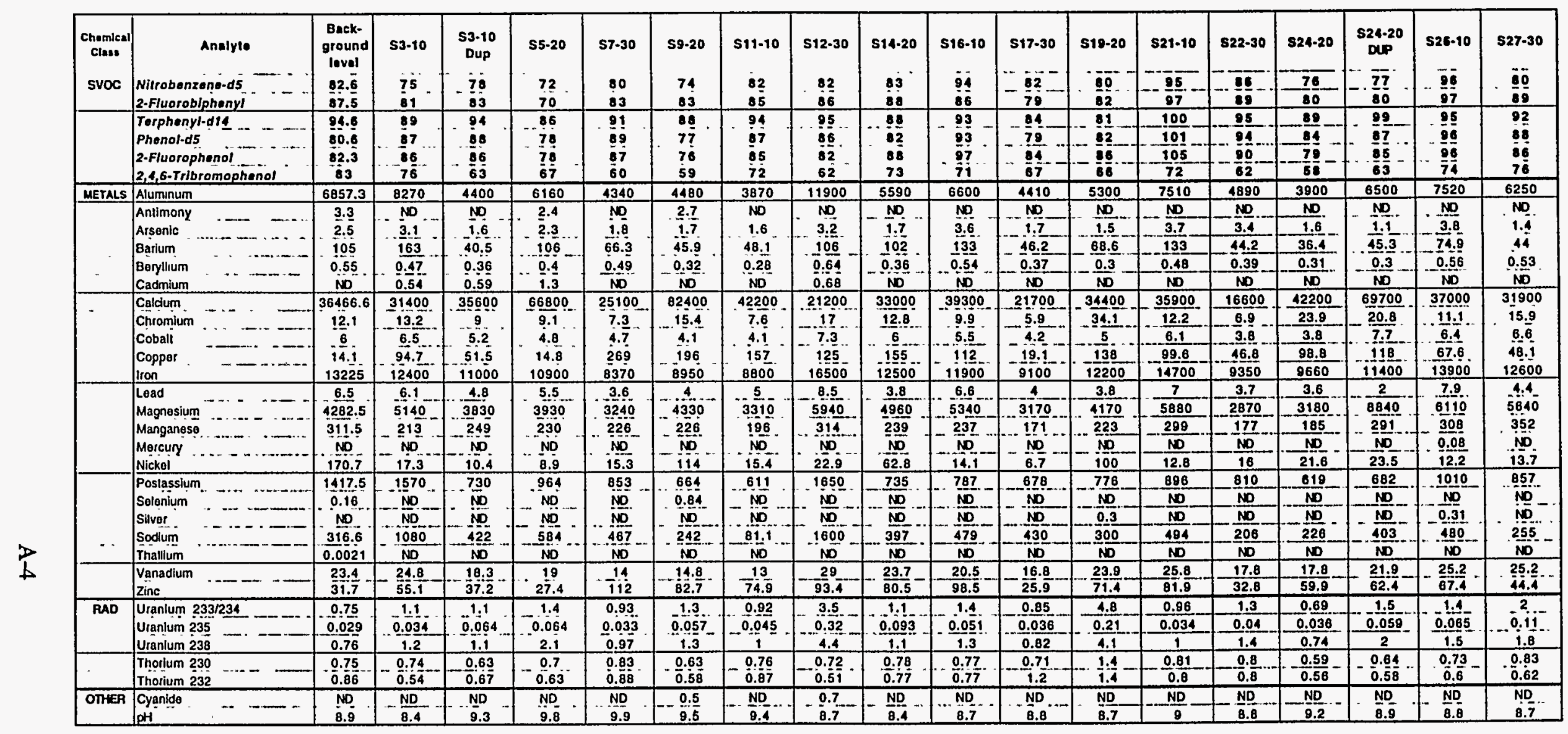


Table 1.1A - Summary of VOC and SVOC Background Soil Samples at RB-11 Site Kirtland AFB, NM.

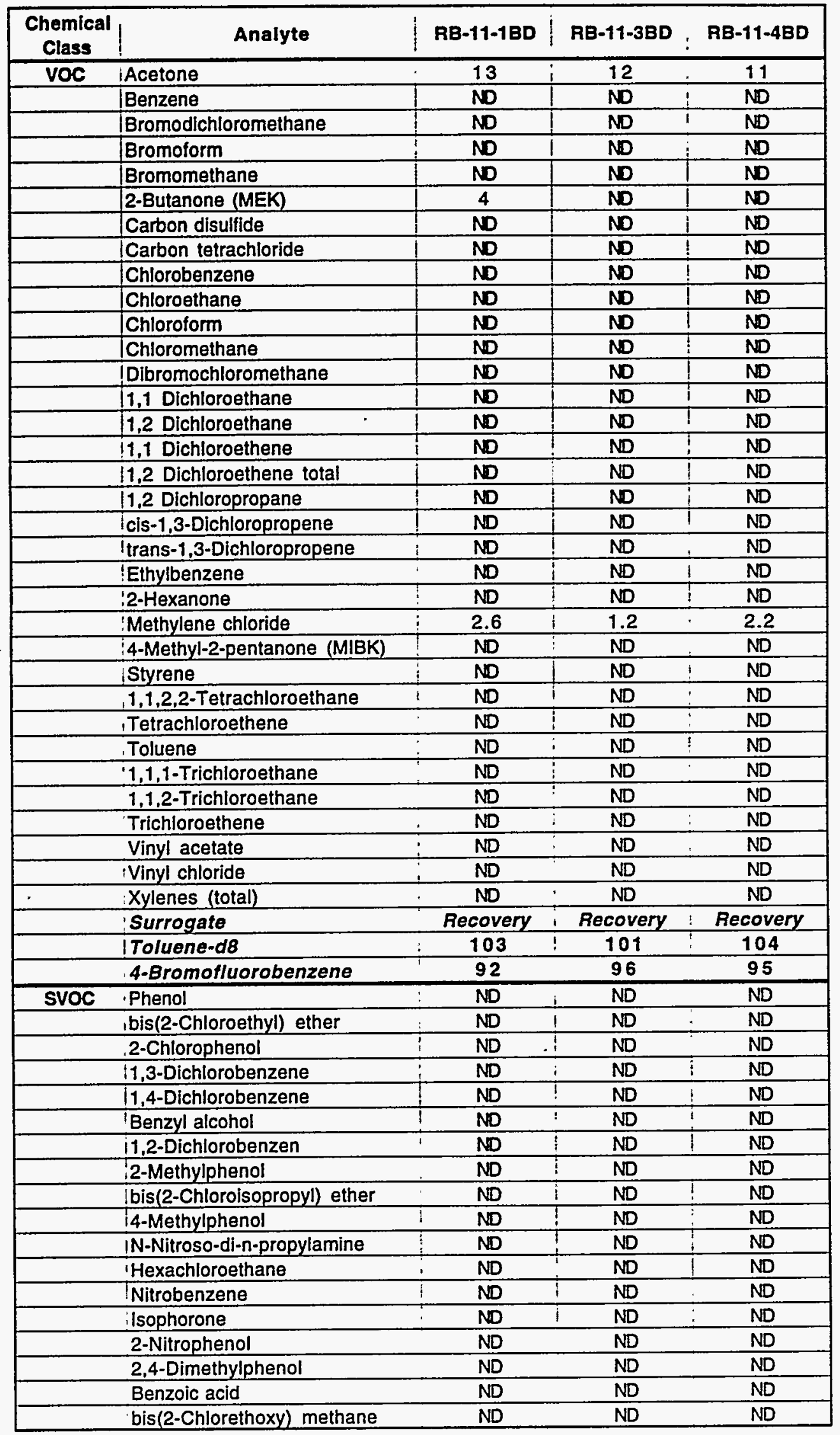


Table 1.1A - Summary of VOC and SVOC Background Soil Samples at RB-11 Site Kirtland AFB, NM.

\begin{tabular}{|c|c|c|c|c|c|c|}
\hline $\begin{array}{c}\text { Chemical } \\
\text { Class }\end{array}$ & Analyte & & $R B-11-1 B D$ & 1 & RB-11-3BD & RB-11-4BD \\
\hline \multirow[t]{2}{*}{ SVOC } & 2,4-Dichlorophenol & & ND & & ND & ND \\
\hline & 1,2,4-Trichlorobenzene & 1 & ND & 1 & ND & ND \\
\hline & INaphthalene & $:$ & ND & & ND & $\mathrm{ND}$ \\
\hline & 4-Chloroaniline & $\vdots$ & $\mathrm{ND}$ & + & ND & $\mathrm{ND}$ \\
\hline & Hexachlorobutadiene & 8 & ND & $i$ & ND & $\mathrm{ND}$ \\
\hline & 4-Chloro-3-methylphenol & 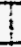 & $\mathbf{N D}$ & & ND & ND \\
\hline & 2-Methy/naphthalene & 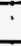 & ND & & ND & $\mathrm{ND}$ \\
\hline & Hexachlorocycolpentadiene & . & ND & & $\mathbf{N D}$ & $\mathrm{ND}$ \\
\hline & 2,4,6-Trichlorophenol & & $\mathrm{ND}$ & & $\mathrm{ND}$ & ND \\
\hline & 2,4,5-Trichlorophenol & 1 & $\mathrm{ND}$ & & $\mathrm{ND}$ & $\mathrm{ND}$ \\
\hline & 2-Chloronaphthalene & 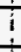 & NO & & ND & ND \\
\hline & 12-Nitroaniline & - & ND & & $\mathrm{ND}$ & ND \\
\hline & Dimethyl phthalate & & ND & & ND & ND \\
\hline & Acenaphthylene & & $\mathrm{ND}$ & 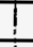 & $\mathbf{N D}$ & ND \\
\hline & 13-Nitroaniline & $i$ & ND & $i$ & ND & ND \\
\hline & Dimethyl phthalate & $\dot{1}$ & ND & $\vdots$ & ND & ND \\
\hline & Acenaphthylene & 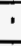 & ND & & ND & ND \\
\hline & 2,4-Dinitrophenol & & ND & 1 & ND & ND \\
\hline & 14-Nitrophenol & & $\mathrm{ND}$ & $i$ & ND & ND \\
\hline & Dibenzofuran & & ND & $T$ & ND & ND \\
\hline & 2,4-Dinitrotoluene & & ND & $i$ & ND & ND \\
\hline & 2,6-Dinitrotoluene & & $\mathrm{ND}$ & $!$ & ND & ND \\
\hline & 'Diethyl phthalate & $\therefore$ & ND & ! & ND & ND \\
\hline & 4-Chlorophenyl phenyl ether & & ND & -1 & $\mathrm{ND}$ & ND \\
\hline & Fluorene & & ND & $!$ & ND & $\mathrm{ND}$ \\
\hline & 4-Nitroaniline & & ND & & $\mathrm{ND}$ & ND \\
\hline & 4,6-Dinitro-2-methylphenol & & ND & 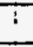 & ND & ND \\
\hline & N-Nitrosodiphenylamine & & ND & & ND & $\mathrm{ND}$ \\
\hline & '4-Bromophenyl phenyl ether & & ND & & ND & ND \\
\hline & Hexachlorobenzene & & $\mathrm{ND}$ & & ND & ND \\
\hline & Pentachlorophenol & & ND & & ND & ND \\
\hline & Phenanthrene & & ND & & ND & ND \\
\hline & Anthracene & & ND & & ND & ND \\
\hline & Carbazole & & ND & & ND & ND \\
\hline & Di-n-butyl phthalate & & ND & & ND & ND \\
\hline & Fluoranthene & & ND & & ND & ND \\
\hline & Pyrene & & ND & & ND & ND \\
\hline & 'Butyl benzyl phthalate & & ND & & ND & ND \\
\hline & 3,3-Dichlorobenzidine & 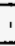 & ND & 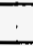 & ND & ND \\
\hline & Benzo(a)anthracene & & ND &. & ND & ND \\
\hline & bis(2-Ethylhexyl) phthalate & & ND & $!$ & ND & ND \\
\hline & Chrysene & & ND & $\vdots$ & ND & $\mathrm{ND}$ \\
\hline & Di-in-octyl phthalate & & $\mathrm{ND}$ & 1 & ND & ND \\
\hline & Benzo(b)fluoranthene & & ND & $i$ & ND & $\mathrm{ND}$ \\
\hline & Benzo(k)fluoranthene & & ND & $\vdots$ & ND & ND \\
\hline & Benzo(a)pyrene & & ND & $i$ & ND & ND \\
\hline & Ideno(1,2,3-cd)pyrene & & ND & 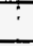 & ND & ND \\
\hline & Dibenz $(a, h)$ anthracene & & ND & 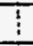 & ND & ND \\
\hline & Surrogate & & Recovery & 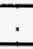 & Recovery & Recovery \\
\hline & Nitrobenzene-d5 & & 87 & & 73 & 88 \\
\hline & 2-Fluorobiphenyl & & 86 & & 68 & 89 \\
\hline & Terphenyl-d14 & & 91 & & 91 & 102 \\
\hline & Phenol-d5 & & 84 & & 77 & 81 \\
\hline & 2-Fluorophenol & & 84 & & 78 & 85 \\
\hline & 2,4,6-Tribromophenol & & 82 & & 84 & 68 \\
\hline
\end{tabular}


Table 1.1B - Summary of Metals, Radioactive, and Other Background Soil Samples at RB-11 Site Kirtland AFB, NM.

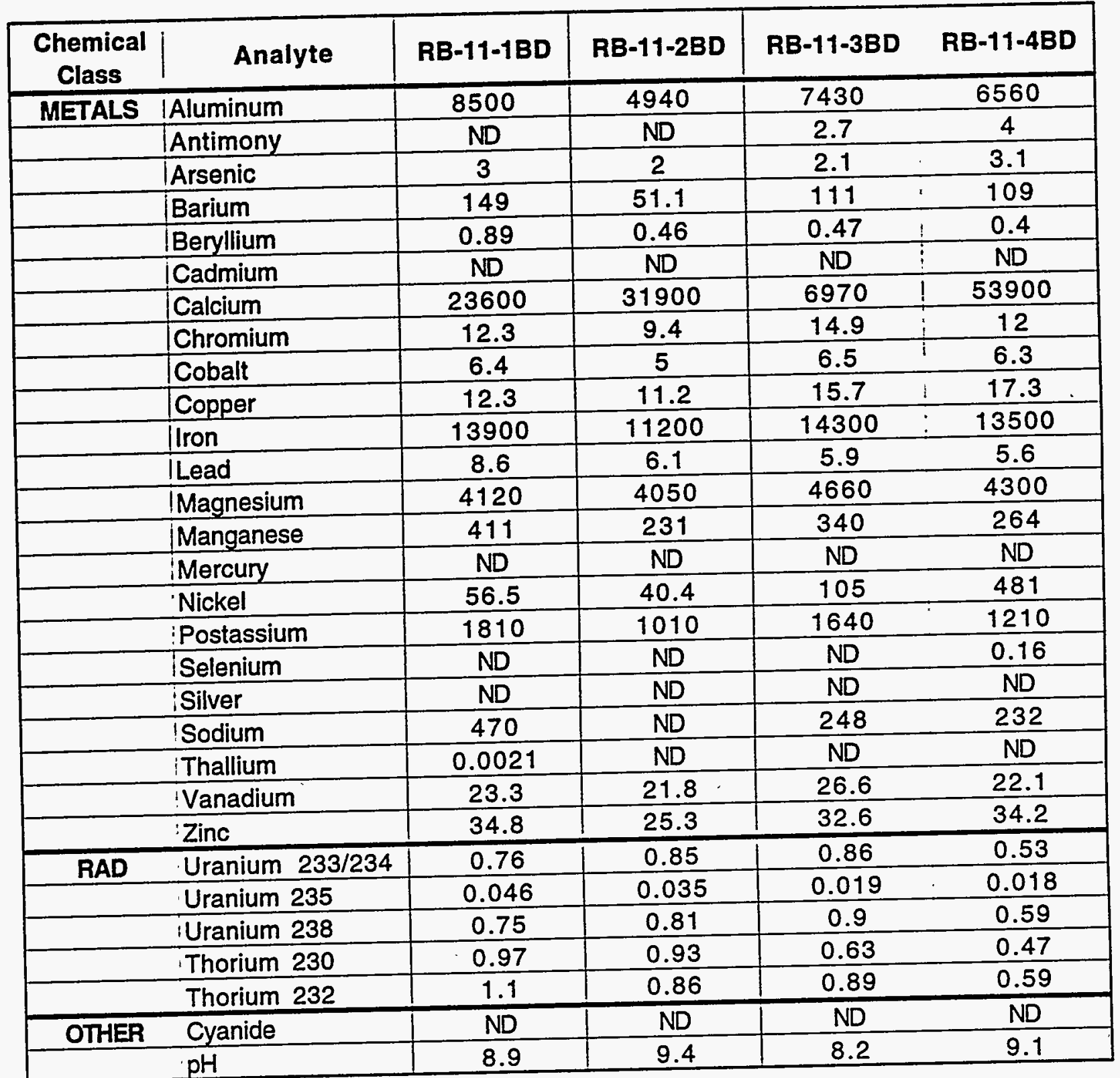


Table 1.1C - Summary of Field Screening Gamma-ray Spectroscopy for Background Soil Samples at RB-11 Site Kirtland AFB, NM.

\begin{tabular}{|c|c|c|c|}
\hline $\begin{array}{c}\text { Chemical } \\
\text { Class }\end{array}$ & Analyte & RB-11-2BD & AB-11-3BD \\
\hline RAD & $1 U-238$ & ND & $\mathrm{ND}$ \\
\hline & TH-234 & ND & ND \\
\hline & U-234 & ND & $\mathrm{ND}$ \\
\hline & |RA-226 & 5.48E-01 & 4.53E-01 \\
\hline & PB-214 & 5.80E-01 & 4.08E-01 \\
\hline & $\mid \mathrm{Bl}-214$ & 5.72E-01 & 4.73E-01 \\
\hline & PB-210 & ND & ND \\
\hline & TH-232 & $7.90 \mathrm{E}-01$ & $6.49 E-01$ \\
\hline & IRA-228 & 7.90 E-01 & $6.49 \mathrm{E}-01$ \\
\hline & AC-228 & 7.13E-01 & 5.85E-01 \\
\hline & TH-228 & $6.61 \mathrm{E}-01$ & 5.76E-01 \\
\hline & RA-224 & $1.55 \mathrm{E}+00$ & $1.94 E+00$ \\
\hline & PB-212 & $6.64 E-01$ & $5.78 E-01$ \\
\hline & $|\mathrm{B}|-212$ & 5.81E-01 & 3.13E-01 \\
\hline & 'TL-208 & 1.99E-01 & 1.67E-01 \\
\hline & U-235 & ND & ND \\
\hline & TH-231 & ND & ND \\
\hline & PA-231 & $\mathrm{ND}$ & ND \\
\hline & $A C-227$ & ND & ND \\
\hline & TH-227 & ND & ND \\
\hline & AM-241 & ND & ND \\
\hline & NP-237 & ND & ND \\
\hline & PA-233 & ND & ND \\
\hline & TH-229 & ND & ND \\
\hline & $A G-110$ & ND & ND \\
\hline & BE-7 & ND & ND \\
\hline & $B A-133$ & ND & $\mathrm{ND}$ \\
\hline & $\mathrm{BA}-140$ & ND & $\mathrm{ND}$ \\
\hline & $\mathrm{BI}-207$ & ND & ND \\
\hline & CD-109 & ND & ND \\
\hline & CE-139 & ND & ND \\
\hline & ICE-144 & ND & ND \\
\hline & $\mathrm{C} 0-56$ & ND & ND \\
\hline & CO-57 & ND & ND \\
\hline & $\mathrm{CO}-58$ & ND & $N D$ \\
\hline & CO-60 & ND & ND \\
\hline & ICR-51 & ND & ND \\
\hline & CS-134 & ND & ND \\
\hline & CS-137 & ND & $\mathrm{ND}$ \\
\hline & CU.64 & $\mathrm{ND}$ & $\mathrm{ND}$ \\
\hline & EU-152 & $\mathrm{ND}$ & ND \\
\hline & EU-154 & ND & ND \\
\hline & EU-155 & ND & ND \\
\hline
\end{tabular}


Table 1.1C - Summary of Field Screening Gamma-ray Spectroscopy for Background Soil Samples at RB-11 Site Kirtland AFB, NM.

\begin{tabular}{|c|c|c|c|}
\hline $\begin{array}{c}\text { Chemical } \\
\text { Class }\end{array}$ & Analyte & RB-11-2BD & RB-11-3BD \\
\hline RAD & FE-59 & ND & ND \\
\hline & !GD-153 & ND & ND \\
\hline & HG-203 & ND & Not Significant \\
\hline & $1-125$ & ND & ND \\
\hline & $! 1-129$ & $\mathrm{ND}$ & ND \\
\hline & $\mid 1-131$ & $\mathrm{ND}$ & ND \\
\hline & $1 \mathrm{~N}-115 \mathrm{M}$ & Short Half-Life & ND \\
\hline & IIR-192 & ND & ND \\
\hline & $K-40$ & $1.42 E+01$ & $1.43 E+01$ \\
\hline & LA-140 & ND & ND \\
\hline & IMN-54 & ND & $\mathrm{ND}$ \\
\hline & NA-22 & ND & ND \\
\hline & iNA-24 & ND & ND \\
\hline & INB-95 & ND & ND \\
\hline & RU-103 & ND & ND \\
\hline & RU-106 & $\mathrm{ND}$ & ND \\
\hline & SB-124 & ND & ND \\
\hline & SB-125 & ND & ND \\
\hline & SB-126 & ND & ND \\
\hline & SC-46 & ND & ND \\
\hline & SN-113 & ND & ND \\
\hline & SR-85 & ND & ND \\
\hline & TA-182 & ND & ND \\
\hline & $T L-201$ & ND & ND \\
\hline & $X E-133$ & ND & ND \\
\hline & $Y-88$ & ND & ND \\
\hline & $\mathrm{ZN}-65$ & ND & ND \\
\hline & ZR-95 & ND & ND \\
\hline
\end{tabular}


Table 2A - Radiometric Analysis Results.

\begin{tabular}{|c|c|c|c|c|c|c|c|c|c|c|c|c|c|c|c|c|c|c|}
\hline $\begin{array}{c}\text { Chemical } \\
\text { Class }\end{array}$ & Analyto & S3-10 & $\begin{array}{c}\text { S3-to } \\
\text { Dup }\end{array}$ & S5-20 & S7-30 & S9-20 & $511-10$ & $\mathbf{S 1 2 - 3 0}$ & $514-20$ & $\$ 16-10$ & $517-30$ & $\$ 19-20$ & $\$ 21-10$ & S22-30 & S24-20 & $\begin{array}{c}\text { S24-20 } \\
\text { DUP }\end{array}$ & $526-10$ & $527-30$ \\
\hline \multirow[t]{2}{*}{ RAD } & Uranium 233/234 & 1100 & 1100 & 1400 & 930 & 1300 & 920 & 3500 & 1100 & 1400 & 850 & 4800 & 960 & 1300 & $\underline{690}$ & 1500 & 1400 & 2000 \\
\hline & Uranium 235 & 34 & 64 & 64 & 33 & 57 & 45 & 320 & 93 & 51 & 36 & 210 & 34 & 40 & 36 & 59 & 65 & 110 \\
\hline & Uranium 238 & 1200 & 1100 & 2100 & 970 & 1300 & 1000 & 4400 & 1100 & 1300 & 820 & 4100 & 1000 & 1400 & 740 & 2000 & 1500 & 1800 \\
\hline & Thorium 230 & 740 & 630 & 700 & 830 & 630 & 760 & 720 & 780 & 770 & 710 & 1400 & 810 & 800 & 590 & 640 & 730 & 120 \\
\hline & Thorium 232 & 540 & 670 & 630 & 880 & 580 & 870 & 510 & 770 & 770 & 1200 & 1400 & 800 & 800 & 560 & 580 & 600 & 100 \\
\hline
\end{tabular}

竞 
Table 2.1A - Radiometric QAVC Results, 27-Oct-94 and 9-Nov-94.

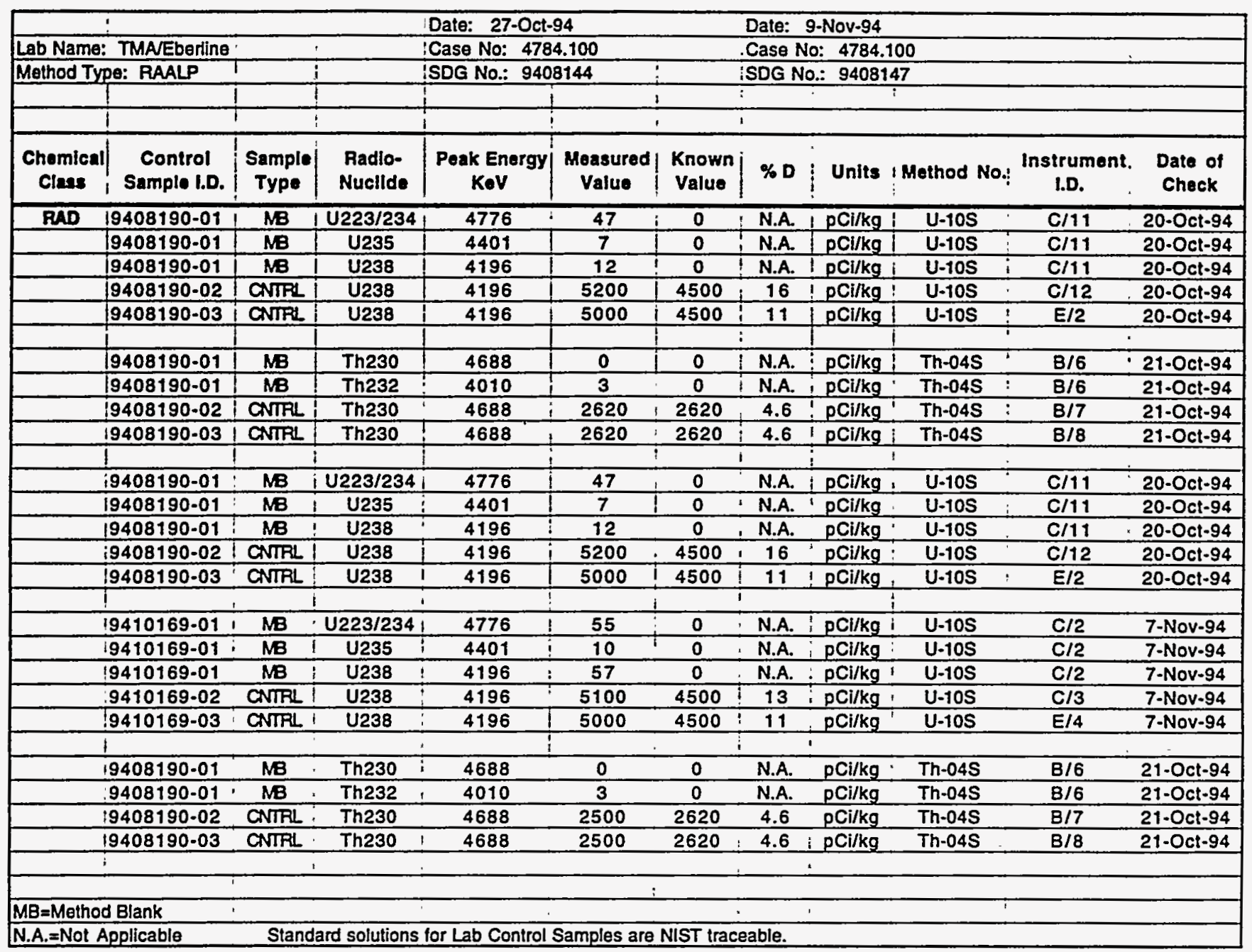




\section{DISTRIBUTION}

Robert L. Johnson, Ph.D.

Aragon National Laboratory

9700 South Cass Avenue

Argonne, IL 60439

3 Mr. Chris Dewitt

Kirtland Air Force Base

$377 \mathrm{ABW} / \mathrm{EM}$

2000 Wyoming SE

Albuquerque, NM 87117-5000

$5 \quad$ MS0131

Dr. Robert Floran

MS0719 Grace Bujewski

MS9018

MS0899

MS0619

Central Technical Files, 8523-2

Technical Library, 13414

Print Media, 12615

MS0100

Document Processing, 7613-2 for DOE/OSTI

Dist-1 